\title{
AVRUPA BİRLİĞİ VE DEMOKRASİ: HALK GÖRÜŞLERİ ANALIZLERI*
}

\author{
Deniz Ilgaz** \\ Nesrin Demir ${ }^{* * *}$
}

\section{$\ddot{O}_{z e t:}$}

Bugün en gelişmiş yönetim biçimi olarak kabul edilen demokrasi kavramı, birlik ve çeşitlilik, özgürlük ve bütünleşme gibi gereksinimleri yönetimde uyumlaştırma çabası olarak görülmektedir. Demokrasiye, hukuk devletine ve insan haklarına saygının teşvik edilmesi, Avrupa bütünleşmesinin birinci amacı olmuştur. Topluluğun kuruluşundan beri iki önemli üyelik koşulundan biri Avrupa devleti olmak, diğeri ise demokratik devlet olmaktır. Ne var ki, demokratik yönetim açısından ileri sayılan ülkelerin kurduğu Birlik, demokrasi açısından sorgulanır duruma gelmiştir. Eurobarometre çalışmaları demokrasi açı̆̆ını kapatmaya ve AB'yi vatandaşla uyumlu karar alma amacına yaklaştırmaya hizmet etmektedir. Daha birleşik, demokratik ve uyumlu bir Avrupa için atılan adımların ancak $A B$ yurttaşlarının onayı ve güveniyle başarıya ulaşması mümkündür. Ekonomik ve sosyal alandaki eleştirilere rağmen Avrupa vatandaşlar yine de $A B$ hakkında olumlu bir imaja sahiptirler. Bu çalışmada Avrupa kamuoyunun AB'nin demokratik yönüne bakışı analiz edilmektedir.

Anahtar Kelimeler: Demokrasi, AB demokrasi açı̆̆ı, Avrupa vatandaşlı̆̆l, Halk görüşleri.

\section{Abstract:}

Democracy, which is considered as the most advanced form of governance, is conceived as a harmonisation effort in reconciling of unity and diversity, freedom and solidarity in administration. Democracy, the rule of law and respect for human rights have been designated as primary aims

\footnotetext{
* Bu çalışmada yararlanılan kaynak: Nesrin Demir (2006). Avrupa Birliği'nde Demokrasi Kavramı, Gelişimi ve Uluslararası Etkileşim, Doktora Tezi, Izmir: Dokuz Eylül Üniversitesi.

${ }^{* *}$ Yard. Doç. Dr., Boğaziçi Üniversitesi, Yabancı Diller Yüksek Okulu.

${ }^{* * *}$ Dr., Dokuz Eylül Üniversitesi.
} 
of European integration from the very beginning. To be a European state and to be a democratic state are the two main conditions of membership since the early days of the integration. The Union, established by states considered as most advanced with respect to democratic administration, has nevertheless started to be questioned due to the lack of democracy. Eurobarometer investigations of the Commission serve to eliminate this deficit and to bring the EU closer to its aim of making decisions in harmony with the choices of EU citizens. Steps towards a democratic Europe, better harmonised and united, can only be successful with the approval and confidence of EU citizens. Although there are economic and social criticisms, European citizens still have a positive image about the EU. This study analyses the public opinion on EU's democracy.

Keywords: Democracy, EU Democratic deficit, European citizenship, Public opinion

\section{Giriş}

Bütünleşme sürecini henüz tamamlamamış, hükümetler arası yapıdan giderek devletler üstü bir yapıya dönüşen ve tarihte daha önce denenmemiş türden federal yönetime ait bazı özellikler yansıtan kendine özgü bir oluşum sergilemekte olan Avrupa Birliği (AB), gerek yeni bir model olmasından kaynaklanan gerekse bir çok ülkeyi bir arada tutabilmenin zorluğundan kaynaklanan bir entegrasyon sorunu yaşamaktadır. Demokratik ilkelerle yönetilmelerine karşın $\mathrm{AB}$ üye ülkeleri $\mathrm{AB}$ projesi içinde demokrasi eksikliği ile karşı karşıya bulunmaktadır. Demokrasi açığının temelinde teknokratik elit kesimin rol oynadığ 1 kurumların varlığı ve kurumlar arası dengeler rol oynasa da, asıl sorun bu çoklu yapıda demokrasinin özünü teşkil eden ortak bir müzakere alanı ve kimliğin oluşturulamayışındadır.

$\mathrm{Bu}$ tür sorunlardan $\mathrm{AB}$ 'nin kısa sürede kurtulması, sorunlarının çok aktörlü ve çok yönlü oluşundan kaynaklanması nedeniyle zor görünmektedir. AB'nin, vatandaşları karşısında tamamen somut bir gerçek haline gelebilmesi için, kamusal alandaki söylem aracılığı ile teşvik edilecek ve böylelikle çeşitli biçimlerde şekillendirilecek bir toplumsal imaj değişikliğine gereksinimi vardır. Kamusal alan, Avrupa bütünleşmesinin üretim ve şekillenme sürecinde son derece önemli bir yere sahiptir. Bu, aym zamanda bir dayanışma biçimi ve dayanışma yolu olarak da görülebilir. Avrupa Birliği üyesi ülkelerin halklarının seslerini duyurabildikleri bir kamusal alanın oluşmasına önemli katkı kaynağı olarak görülebilecek 
Eurobarometre çalışmaları, AB'nin demokrasi açığını kapatmasında da rol oynayabilecek potansiyele sahiptir.

Bu çalışmada, özellikle 2006 yılında yürütülen Standard ve Special Eurobarometre çalışmalarına bakarak ve Avrupa halklarının çeşitli konulardaki görüşlerine yer verilerek, Avrupa Birliği'nin bugününü ve geleceğini daha demokratik bir temel üzerine nasıl inşa edebileceği sorgulanmaktadır. Birlik kurumları, Eurobarometre sonuçlarını yorumlayarak Avrupa Birliği'nin demokrasi açığını gidermek üzere adımlar atabilecekleri gibi bu görüşlerden çeşitli politikalarını şekillendirmede de yararlanabilirler. Birlik halkının büyük çoğunluğu bugün ülkesinin $\mathrm{AB}$ üyeliğinden yarar sağladığına inansa da, AB üyeliği için belirtilen destek kişinin yaşına, eğitim düzeyine, mesleğine ve $\mathrm{AB}$ konusundaki kişisel bilgisine bağlı olarak önemli değişim göstermektedir. Sadece bu gerçek bile $\mathrm{AB}$ içindeki yönetici elitlerin izlemesi gereken yeni politikalara ışık tutmaktadır.

Avrupa düzeyinde yapılan araştırmalarda kanıtlandığ üzere Avrupa vatandaşı, şimdiki durumda Birliği desteklemekte ve AB'nin Avrupa'da barışı sağlamada başarılı olduğuna inanmaktadır. Ne var ki $A B$, başta işsizlik olmak üzere ekonomik sorunlara çözüm getirebildiği, sosyal dayanışmayı sağlayabildiği ölçüde, siyasi bir birlik oluşturma sürecini tamamlayacak potansiyele sahip görünmektedir. Ancak değişen dünya koşulları içinde, bu yapının hangi düzeye ve yöne doğru gideceği zaman içinde görülecektir.

Avrupa Komisyonu bünyesinde "Eurobarometre" araştırmaları adı altında her yıl AB'ye yönelik olarak çeşitli konularda araştırmalara yer verilmektedir. Halkın karar verme sürecine katılım eksikliğini de içeren demokrasi açığının giderilmesine yönelik olarak değerlendirilebilecek bu girişim, Avrupa Komisyonu tarafından yürütülen ölçümler ve analizlerdir. Eurobarometre başlığı altında; özel (special), standart ve aday ülkelere yönelik olmak üzere genel olarak üç tür araştırma çeşidi bulunmaktadır. "Halk görüşleri analizleri" adı altında ortaya çıkan bu araştırmaların şüphesiz $\mathrm{AB}$ gibi demokratik temele dayalı bir yapıda, halkın görüşlerinin tartışılmaz bir önem taşıyacağı açıktır. Doğrudan halkın görüşlerine yer veren bu tür araştırmalar, Birliğin geleceğinin şekillenmesinde ve bu yapının sürdürülmesinde dikkate alınması gereken ip uçlarını ortaya koymaktadır. 


\section{Avrupa Birliği ve Demokrasi}

Halkın yönetimi anlamına gelen demokrasi, tarih boyunca farklı toplumlar tarafından farklı tanımlamalarla bugüne gelmiştir. Demokrasi kavramının temel hedeflerinin başında özgürlük ve eşitlik gelmektedir. Özgür düşünceye sınır getiren toplumlarda demokrasiden söz edilemez. (Selçuk, 1999:23) Eşitlik ise, vatandaşların yasalar önünde ve devlet hizmetlerinden pay almada yaşadıkları eşitliktir. Eğitim, iş bulma, sağlık, kültürel olanaklar, toplumsal güvenceler gibi temel hak ve özgürlükleri kullanmada görülür. (Şaylan, 1980:110) Halkı, kendi seçtiği kişilerin temsil etmesi anlamına gelen siyasal temsil kavramı da demokrasi için en gerekli unsurlardan biridir. (Gözler, 2001:117) Halkın, kendisini yönetecek kişileri seçtikten sonra siyasi iktidarın aldığı kararları etkileyebilmesi, uygulama kararlarına örgütleri aracılığıyla katılabilmesi anlamına gelen katılımcılık olgusu da demokrasi ilkelerinden biridir. (Tanilli, 1990:37-38) Özgürlüğün somutlaştırılmış biçimi olan haklar ise, insan haklan, kamu özgürlüğü, kişi hakları, vatandaş hakları, temel haklar, anayasal haklar gibi kavramlar kullanılarak belirtilmektedir (Gözler, 2001: 146-147)

Demokratik yönetim, birlik ve çeşitliliğin, özgürlük ve bütünleşmenin uyuşma çabası olarak tanımlanabilir. Bugünün çoğunluğunun yarın azınlığa dönüşebileceğini ve çoğunluğun çıkarlarından farklı çıkarları temsil edecek azınlığın temel haklarını yerine getirme konusunda, çoğunluğa karşı çıkmayacağı biçimde düzenlenmiş yasalarca yönetilebileceğini kabul eden bir yönetim biçimidir. (Schmidt, 2002:185-186) Demokrasi aynca bireysel ve ortak özgürlüğün toplumsal kurumlarca tanınmasına dayanır. (Touraine, 2002:30) Bir siyasal rejim olarak demokrasi, insan haklarının gerçekleştirildiği düzeni temsil etmektedir. Demokrasinin düşünsel temelini oluşturan insan hakları, 20. yüzyıla kadar ulusal sınırlar içinde değerlendirilirken, son yarım yüzyıl içinde korunma kapsamını uluslararası alana genişletmiştir. Uluslararası alanda demokrasiyi teşvik eden, koruyan bir dizi mekanizma oluşturulmuş, ve demokrasinin gelişimi çeşitli girişimlerle desteklenmiştir. II. Dünya Savaşı sonrasında Avrupa kıtasındaki ülkelerin kalkınmalarını kolaylaştırmak amacıyla bir Ekonomik Topluluk olarak başlatılan entegrasyon hareketi, yarım yüzyıl içerisinde Birlik adını alarak 20. yüzyılın en büyük sosyal ve politik projesini gerçekleştirme yoluna girmiştir. Birbirini izleyen genişleme ve derinleşme süreçleriyle Birlik, yetki alanını parasal bütünleşmeden sosyal politikalara, ortak dış ve güvenlik politikasından çevreye, adalet ve içişlerinden bölgesel ve de komşuluk politikalarına kadar yaymıştır. Özgürlük, barış, güvenlik ve ekonomik refah alanı olarak tasarlanan Avrupa Birliği, ortak hedefler 
belirlenerek bunların tüm katılımcılar için yararlı olacak biçimde bir üst otorite denetiminde gerçekleştirilmesi yolunu seçmiştir. Üye Devletlerden Topluluğa bir takım yetkilerin aktarılmasıyla birlikte ulusal ve uluslarüstü düzeyde siyasal yetenekler artmış, ekonomik ve siyasal alanda ortak etkinlik ve gelişme yoları açılmıştır. (Canbolat, 1998:96-97)

Avrupa Topluluğu en başından itibaren demokratik ilkelere ve değerlere sayg1 gösterme çabası içine girmiştir. Özellikle 1987 yılında yürürlüğe giren Tek Avrupa Senedi'nin başlangıç bölümünde insan hakları ve demokrasiye olan bağlılık ifadeleri yer almaktadır. Demokrasinin, üye devletlerin anayasa ve yasalarında, İnsan Hakları Evrensel Bildirgesi'nde, İnsan Haklarını ve Temel Özgürlükleri Koruma Avrupa Sözleşmesi ve Avrupa Sosyal Şartı'nda yer alan temel haklara (özgürlük, eşitlik ve sosyal adalete) dayanarak ilerleyeceği belirtilmiştir. (Duparch, 1992:30) Kendine özgü bir yapı ve hukuk kurallarına (Tekinalp, 2000:67-70) sahip olan Avrupa Birliği kurumlarının aldıkları kararlar, hem ülke hükümetlerine bağlayıcılık, hem de üye ülke halklarına doğrudan hak, özgürlük ve yükümlülükler getirdiklerinden, son yirmi yıl içinde Birlik'te "demokrasi açığı" ve "demokratik meşruiyet" üzerinde tartışmalar gündeme gelmektedir. (Schmitter, 2000:4-10) Tek Avrupa Senedi'nden başlayarak bugüne kadar yapılan antlaşmalarda (Maastricht, Amsterdam, Nice, ve henüz yürürlüğe girmemiş olan Avrupa Anayasal Antlaşması) demokrasi eksikliğinin giderilmesine yönelik bazı adımlar atıldıysa da, sorun halen canlılığını korumaktadır. Birliğin demokrasi sorunu başta kamusal alan eksikliği olmak üzere, Avrupa kimliği oluşturulmasındaki güçlükler, Avrupa siyasi partilerinin olmayışı, Topluluk düzeyinde güçlü sivil örgütlenmelerin sağlanamaması gibi konularda odaklanmakta, halkın içinde bulunmadığı bir bütünleşmenin sorgulanmakta olduğuna işaret etmektedir. (Calhoun, 2004; Eder, 2001; Habermas, 2000; Lord, 1998; Schmidt, 2002; Streek, 2001; Weiler, 1999)

\section{Avrupa Birliği'ne Üye Ülkeler ve Yeni Üye Olan Ülkelere İliş̧kin Kimlik ve Değerler Analizi}

2003 yılında Eurobarometre araştırmalarında 13 ülke (Bulgaristan, Kıbrıs, Çek Cumhuriyeti, Estonya, Macaristan, Latviya, Litvanya, Malta, Polonya, Romanya, Slovakya, Slovenya ve Türkiye) arasında "sosyo-politik değerler ve kimlikler" başhıklı bir çalışma yapılmıştır. Bu araştırmada, katılımcılara yöneltilen "size göre en önemli değer hangisidir?" sorusuna verilen karşılıklar şu şekildedir: Barış; İnsan Yaşamına Saygı; İnsan Hakları; Hoşgörü; Hukuk Kuralları; Bireysel Özgürlük; Demokrasi; Din; 
Dayanışma; Eşitlik; Kendini Gerçekleştirme; Başka Kültürlere Sayg1 (Standart Eurobarometer, 2004).

Genel olarak bakıldığında; 2004 yılında aday olmuş 10 ülke vatandaşları için en önemli sosyo-politik değerin \%56'lık bir oranla "banş̧" olduğu görülmektedir. Ancak, çalışmanın yapıldığı o tarihte üyelik müzakerelerine başlamamış olan üç aday ülkenin (Romanya, Bulgaristan ve Türkiye) vatandaşları için "insan haklarn" \%50'lik bir oranla "barış” kadar önemli bir yer tutmaktadır. 10 üye ülke vatandaşları arasında "insan hakları" \%42'lik bir oranla 3. sırada yer almıştır. "Barış" 3 aday ülke için \%49'luk bir oranla ikinci sırada yer almıştır. "İnsan haklarına saygı" ise iki grup arasında $\% 2$ 'lik bir farkla 3. sırada yer almıştır. 10 üye ülke vatandaşları arasında \%23'lük bir oranla "hoşgörü" 4. sırada yer almıştır. Aday ülkeler arasında ise bu oran \%18'e inmektedir. "Eşitlik" \%26'lık bir oranla aday ülkeler arasında 4. sırada yer almasına karşılık bu oran, 10 yeni üye ülke vatandaşları arasında \%13'e düşmektedir. Diğer değerler ise; "hukuk kuralları" \%21, "demokrasi" \% 17, "din" \% 14, "dayanışma" \% 14, "kendini gerçekleştirme" \%12'dir. Bu 10 üye ülke vatandaşları için seçilen sosyopolitik değerler arasında en düşük orana \%5 ile "başka kültürlere saygı" sahip olmuştur. 3 aday ülkede ise "din" \%23 ve "demokrasi" \%22'lik bir oranla 5. ve 6. sırada yerini alarak önemini ortaya koymuştur. "Başka kültürlere saygı" konusu ise, aday ülkelerde de yine \%5'lik bir oranla sonuncu sıraya yerleşmiştir.

Bu iki grup, 15 üye ülke vatandaşları ile karşılaştırıldığı zaman "barış"ın $\% 60$ 'lı bir oranla 1. sırada yer aldığı görülür. "İnsan yaşamına saygı" \%46'lık bir oranla 2. sirada yer alırken, "insan hakları" \%37 ile 3. sirada yer almıştır. Araştırma sonuçlarına bakıldığında, sosyo-politik değerler arasında "din" ve "bireysel özgürlük" değerlerinin 3 grup arasında oransal olarak farklılıklar göze çarpmaktadır. "Bireysel özgürlük" 15 üyeli AB vatandaşları için \%30'luk bir değere sahipken, aday ülkelerde (Türkiye, Bulgaristan ve Romanya), \%17 ve 10 yeni üye ülkede \%18'lik bir oranla ortaya çıkmaktadır. "Din" ise, 15 üye ülkede oldukça düşük bir oran olan $\% 7$ iken, aday ülkelerde diğer iki gruptan açık arayla \%23'lük bir oranla kendini göstermektedir. 10 ülkede bu değere karşılık gelen oran \%14'tür. "Başka kültürlere saygı" 15 üye ülke vatandaşları için \%8 oranına sahip olmuştur. En önemli 3 sosyo-politik değerin ülkelere göre oranları Tablo 1 'de gösterilmiştir. Tablo 1'de görüldüğü gibi; "barış" \%72'lik bir oranla Macaristan'da 1. sırada yer alırken, \%61'lık bir değerle Bulgaristan ve Slovakya'da 2. sırada yerini korumuştur. Bu değerin en düşük orana ulaşı̆ı̆ı ülke ise \%44'lük bir oranla Türkiye olduğu ortaya çıkmaktadır. 
Tablo 1: Sosyo-Politik Değerlerin Ülkelere Göre Yüzde Oranları

\begin{tabular}{|c|c|c|c|}
\hline \multirow[b]{2}{*}{ Ülkeler } & \multicolumn{3}{|c|}{ Sosyo-Politik Değerler } \\
\hline & Barış & Insan Hakları & $\begin{array}{c}\text { Ínsan Yaşamına } \\
\text { Saygı }\end{array}$ \\
\hline Bulgaristan & $\% 61$ & $\% 51$ & $\% 47$ \\
\hline Kibris & $\% 54$ & $\% 54$ & $\% 45$ \\
\hline Çek Cum. & $\% 58$ & $\% 39$ & $\% 32$ \\
\hline Estonya & $\% 51$ & $\% 36$ & $\% 51$ \\
\hline Macaristan & $\% 72$ & $\% 36$ & $\% 52$ \\
\hline Latviya & $\% 60$ & $\% 54$ & $\% 49$ \\
\hline Litvanya & $\% 49$ & $\% 56$ & $\% 39$ \\
\hline Malta & $\% 69$ & $\% 55$ & $\% 38$ \\
\hline Polonya & $\% 50$ & $\% 43$ & $\% 55$ \\
\hline Romanya & $\% 58$ & $\% 48$ & $\% 37$ \\
\hline Slovakya & $\% 61$ & $\% 43$ & $\% 26$ \\
\hline Slovenya & $\% 67$ & $\% 47$ & $\% 36$ \\
\hline Türkiye & $\% 44$ & $\% 52$ & $\% 49$ \\
\hline
\end{tabular}

Kaynak: (Standart Eurobarometer, 2004).

Bu konuyla ilgili olarak; "ülkenizi en iyi biçimde temsil eden üç değer hangisidir?" sorusuna karşılık alınan cevaplara bakıldığında şunlar görülmektedir: Yeni üye olan 10 ülke vatandaşlarının yarısından azı (\%42), "barış"1n ülkelerini en iyi şekilde temsil eden değer olarak ifade ettiğini belirtmiştir. Aday ülkeler ise \%37'lik bir oranla yeni üye ülkelerin arkasından gelmektedir. İkinci olarak, yeni üye ülke vatandaşlanı \%30'luk bir aranla "din'i". ülkelerini en iyi temsil eden değer olarak belirtmiştir. Bu iki değeri \%26'lık bir oranla "demokrasi" izlemektedir. Aday ülke vatandaşlarına bakıldığında ise; daha farklı bir durum ortaya çıkmaktadır. Birinci sırada "barış"ın geldiği, ikinci sırada ise \%30'luk bir oranla "demokrasi”nin izlediği, 3. sırada ise \%29'luk bir oranla "insan hakları"nın en önemli değer olarak yerini bulduğu görülmektedir.

Ülkeler bazında bakıldığında; en önemli 3 değer arasında "barış"ın $\% 60$ 'lık bir oranla Bulgaristan'da ön sırada olduğu, bu değerin en düşük oranı ise \%43 ile Slovakya'da elde edildiği görülmektedir. "Demokrasi" ise en yüksek oranı \%60 ile Kıbrıs'ta ve \%33 ile Türkiye'de alarak bu ülkelerde birinci sıraya yerleşmiştir. "Din" konusunda ise en yüksek oran \%48 ile Maltalılar ve \%44 ile Polonyalılar tarafından en önemli değer olarak yerini almıştır. "Demokrasi"yi ikinci sırada ülkelerini temsil eden en önemli değer olarak gören ülkeler ise şunlardır; Çekler, Estonyalılar, Bulgarlar, Latviyalılar, Litvanyalılar ve Slovenyalılardır. "Din"i ikinci sıraya koyan 
ülkeler ise; Kıbrıs, Romanya ve Slovakya'dır. "Barış" Polonya ve Malta'da ikinci sırada yer almaktadır. Türkiye'de ise, "demokrasi”den sonra "insan hakları" ikinci sırada yer almaktadır.

Yine bu iki grup ülke vatandaşlarına "size göre Avrupa Birliği'ni en iỳi biçimde temsil eden en önemli 3 değer hangileridir?" sorusuna verilen yanıtlar şu biçimdedir; "insan hakları", "hukuk kuralları" ve "demokrasi"nin öne çıktığı görülmektedir. Yeni üyelerin yarısından biraz azı \%41'lik bir oranla "insan hakları"nı AB'yi en iyi temsil eden değer olarak görürken, 3 aday ülkede bu oran \%52'ye ulaşmıştır. AB'yi en iyi ifade eden değerin "demokrasi” olduğunu düşünenler, 10 üye ülke vatandaşının \%34'ünü oluşturarak ikinci sıraya koymuştur. İkinci grup ülkeler ise "demokrasi”ye \%35'lik bir oran vererek bu değeri "insan yaşamına saygı" değerinin arkasına yerleştirmiştir. "Hukuk kuralları" ise 10 yeni üye için \%29'luk bir oranla 3. sırada yerini alırken, "barış" \%27'lik bir oranla 4. sırada yer almıştır. AB'yi en iyi temsil eden değer olarak "din"'in yeri ise \%3'lük bir oranla en son sırada kalmıştır.

15 üyeli $\mathrm{AB}$ üye ülke vatandaşlarıyla, iki grup ülke vatandaşlarının görüşleri karşılaştırıldığında ortaya ilginç sonuçlar çıkmaktadır. "Barış"'1 $A B$ 'yi en iyi temsil eden değer olarak görülmesinde iki grup ülke 4. sıraya koyarken, 15 üyeli $\mathrm{AB}$ ülke vatandaşları \%38'lik bir oranla birinci sıraya koymuştur. "İnsan hakları"nı \%36'lık bir oranla 2. sıraya koyan 15 üyeli $\mathrm{AB}$ vatandaşları birinci grup ülkenin bu değere karşıllk olarak verdiği $\% 41^{\prime}$ 'lik oranın gerisinde kalmıştır. Bu değer ikinci grup olan aday ülkelerde \%52'ye ulaşmıştır. "Demokrasi" konusunda ise, 15 üyeli $\mathrm{AB}$ vatandaşları $\% 30$ 'luk bir oranla bu değere 3. sırayı uygun görmüştür. Bu oran iki grup üye ülke vatandaşlarından daha düşük bir seviyededir.

Ülkeler bazında ilk iki grup ülkeye bakıldığında; AB'yi en iyi temsil eden değer olarak şu sonuçlar ortaya çıkmaktadır. "İnsan hakları" iki grup ülkeden 11 'inde birinci sırada yer almıştır. Bu ülkeler içinde Kıbrıs halkı “insan hakları"na \%57'lik oranla en yüksek değeri vermiştir. En düşük değer ise \%37'lik oran ile Polonya ve Slovakya'da görülmüştür. "Demokrasi"nin AB'yi en iyi temsil eden değer olarak görüldügü yer \%36 oranıyla Slovakya'dır. "Demokrasi”yi ikinci sıraya koyan ülkeler ise; Çek Cumhuriyeti, Litvanya, Malta, Polonya ve Romanya'dır. 


\section{Avrupa Birliği’nde Vatandaşlık ve Ait Olma Hissi ile İlgili Olarak Yapılan Analizler}

$\mathrm{Bu}$ araştırmada, 15 üyeli $\mathrm{AB}$ vatandaşlarının kişisel bakış açılarına göre sosyo-politik değerleri “yüksek oran", "15 üye ülke ortalaması" ve "düşük oran" şeklinde nasıl algıladıkları Tablo 2a'da görüldüğü gibidir (Special Eurobarometer, 2004). Tablo 2.a incelendiğinde; $\mathrm{AB}$ vatandaşlarının kişisel bakış açılarına göre en önemli sosyo-politik değerlerin \%60'lı bir oranla "barış" olduğu görülmektedir. Bu noktada Almanya \%66'lık oranla en yüksek değere ulaşmıştır. 15 üyeli AB vatandaşının \%46'sı "insan yaşamına saygı"yı ikinci sıraya koymuş ve burada İtalya öne çıkmıştır. Bu konuda İsveç en düşük oran olan \%38 ile en alt değere ulaşmıştır. "İnsan hakları" İsveç vatandaşları arasında \%57'lik oranla zirveye oturmuştur. "Bireysel özgürlük" değeri üzerine yapılan anketlerde ise $\% 51$ oy oranılla Avusturya önde giderken, \%19 ile Yunanistan en düşük seviyede yer almıştır. "Demokrasi" en önemli 5.değer olarak \%46'lik bir oranla İsveç ve \%43'lük oranla Danimarka vatandaşları içinde en yüksek değer olarak addedilmiştir. “Hoşgörü" konusunda Hollanda \%31'lik bir orana sahip olurken, en düşük değer \%0 ile Yunanistan'in olmuştur.

Tablo 2.a: AB Vatandaşlarının Sosyo-Politik Değerlere Yönelik Kişisel Bakış Açılarının Ülkeler Bazında Yüzde Oranları

\begin{tabular}{|c|c|c|c|}
\hline Değerler & $\begin{array}{l}\text { Yüksek } \\
\text { Oranlar }\end{array}$ & $\begin{array}{l}15 \text { üye ülke } \\
\text { ortalaması }\end{array}$ & $\begin{array}{c}\text { Düşük } \\
\text { oranlar }\end{array}$ \\
\hline Barış & $\begin{array}{c}\text { \%66 Almanya, } \\
\% 64 \text { Italya }\end{array}$ & $\% 60$ & $\begin{array}{l}\text { \%51 Hollanda, } \\
\text { \%53 Fransa }\end{array}$ \\
\hline İnsan Yaşamına Saygı & $\begin{array}{l}\text { \%55 İtalya, } \\
\text { \%54 İrlanda }\end{array}$ & $\% 46$ & $\begin{array}{c}\text { \%36 İsveç, } \\
\% 38 \text { Avusturya }\end{array}$ \\
\hline İnsan Hakları & $\begin{array}{c}\text { \%57 İsveç, } \\
\% 46 \text { Lüksemburg }\end{array}$ & $\% 37$ & $\begin{array}{l}\text { \%26 Portekiz, } \\
\% 27 \text { Danimarka }\end{array}$ \\
\hline Bireysel Özgürlük & $\begin{array}{l}\text { \%51 Avusturya, } \\
\% 44 \text { Almanya }\end{array}$ & $\% 30$ & $\begin{array}{c}\text { \%19 Yunanistan, } \\
\% 20 \text { İsvec }\end{array}$ \\
\hline Demokrasi & $\begin{array}{c}\text { \%46 İsveç, } \\
\text { \%43 Danimarka }\end{array}$ & $\% 25$ & $\begin{array}{l}\text { \%14 Finlandiya, } \\
\% 19 \text { İngiltere }\end{array}$ \\
\hline Hoşgörü & $\begin{array}{l}\text { \%31 Hollanda, } \\
\% 28 \text { Fransa }\end{array}$ & $\% 19$ & $\begin{array}{c}\% 0 \text { Yunanistan, } \\
\% 9 \text { İtalya }\end{array}$ \\
\hline Eşitlik & $\begin{array}{l}\text { \%26 Portekiz, } \\
\% 24 \text { İspanya }\end{array}$ & $\% 16$ & $\begin{array}{c}\text { \%8 Almanya, } \\
\% 14 \text { Lüksemburg }\end{array}$ \\
\hline Hukuk Kuralları & $\begin{array}{l}\text { \%33 Finlandiya, } \\
\% 28 \text { Ingiltere }\end{array}$ & $\% 15$ & $\begin{array}{c}\text { \%7 Fransa, } \\
\text { \%8 Belçika, } \\
\text { Lüksemburg, } \\
\text { Hollanda }\end{array}$ \\
\hline
\end{tabular}


Tablo 2.a (Devamı)

\begin{tabular}{|c|c|c|c|}
\hline Değerler & $\begin{array}{c}\text { Yüksek } \\
\text { Oranlar }\end{array}$ & $\begin{array}{l}15 \text { üye ülke } \\
\text { ortalaması }\end{array}$ & $\begin{array}{c}\text { Düşü̈k } \\
\text { oranlar }\end{array}$ \\
\hline Kendini Gerçekleştirme & $\begin{array}{l}\text { \%21 İrlanda, } \\
\text { \%19 Fransa }\end{array}$ & $\% 14$ & $\begin{array}{c}\text { \%1 Danimarka, } \\
\text { \%7 Italya }\end{array}$ \\
\hline Dayanıșma & $\begin{array}{l}\text { \%24 Portekiz, } \\
\% 23 \text { Fransa }\end{array}$ & $\% 13$ & $\begin{array}{l}\% 5 \text { İrlanda, } \\
\% 6 \text { İngiltere }\end{array}$ \\
\hline Diğer Kültürlere Saygı & $\begin{array}{c}\text { \%12 Lüksemburg, } \\
\% 10 \text { İtalya }\end{array}$ & $\% 8$ & $\begin{array}{c}\% 4 \text { Finlandiya, } \\
\text { Avusturya }\end{array}$ \\
\hline Din & $\begin{array}{c}\text { \%30 Yunanistan, } \\
\text { \%13 Portekiz }\end{array}$ & $\% 7$ & $\begin{array}{c}\text { \%3 Fransa, İsveç, } \\
\text { Lükssembourg }\end{array}$ \\
\hline Fikrim Yok & $\begin{array}{l}\text { \%4 Lüksemburg, } \\
\text { \%3 Avusturya }\end{array}$ & $\% 1$ & $\begin{array}{l}\text { \%0 Hollanda, } \\
\text { Yunanistan }\end{array}$ \\
\hline Bunlardan Hiçbiri & $\begin{array}{l}\text { \%2 Avusturya, } \\
\% 1 \text { Almanya }\end{array}$ & $\% 0$ & $\begin{array}{l}\text { \%0 Finlandiya, } \\
\text { Yunanistan }\end{array}$ \\
\hline
\end{tabular}

Kaynak: (Special Eurobarometer, 2004).

Yine aynı başlık altında yapılan bir diğer araştırmada, "AB vatandaşlarının kendi ülkelerini en iyi temsil eden değerler nedir?" sorusuna verilen yanıtların oranı, Tablo $2 b$ 'de görüldüğü gibidir.

Tablo 2.b: AB Vatandaşlarının Kendi Ülkelerini En İyi Temsil Ettiklerine İnandıkları Değerlerin Ülkelere Göre Yüzde Oranları

\begin{tabular}{|c|c|c|c|}
\hline Değerler & Yüksek Oran & $\begin{array}{l}15 \text { AB Üye Ülke } \\
\text { Ortalaması }\end{array}$ & Düşük Oran \\
\hline Demokrasi & $\begin{array}{c}\text { \%67 Danimarka, } \\
\text { \%65 İsveç }\end{array}$ & $\% 46$ & $\begin{array}{c}\% 32 \text { Lüksembourg, } \\
\% 35 \text { İlanda }\end{array}$ \\
\hline Barış & $\begin{array}{l}\% 62 \text { Yunanistan, } \\
\% 50 \text { Avusturya }\end{array}$ & $\% 39$ & $\begin{array}{c}\% 28 \text { Hollanda, } \\
\% 30 \text { İngiltere }\end{array}$ \\
\hline Ínsan Hakları & $\begin{array}{l}\text { \%54 Fransa, } \\
\text { \%43 Almanya }\end{array}$ & $\% 34$ & $\begin{array}{l}\text { \%21 Portekiz } \\
\% 25 \text { İtalya }\end{array}$ \\
\hline Hukuk Kuralları & $\begin{array}{l}\% 47 \text { Finlandiya, } \\
\% 43 \text { Almanya }\end{array}$ & $\% 32$ & $\begin{array}{l}\text { \%18 Yunanistan, } \\
\text { Lüksembourg }\end{array}$ \\
\hline $\begin{array}{l}\text { İnsan Yaşamına } \\
\text { Sayg1 }\end{array}$ & $\begin{array}{c}\text { \%35 İrlanda, } \\
\% 26 \text { Lüksembourg }\end{array}$ & $\% 21$ & $\begin{array}{l}\% 13 \text { Hollanda, } \\
\% 17 \text { Finlandiya }\end{array}$ \\
\hline $\begin{array}{l}\text { Bireysel } \\
\text { Özgürlük }\end{array}$ & $\begin{array}{l}\% 26 \text { Hollanda, } \\
\text { İrlanda }\end{array}$ & $\% 20$ & $\begin{array}{l}\text { \%10 İsveç, } \\
\% 14 \text { İspanya }\end{array}$ \\
\hline Dayanışma & $\begin{array}{l}\% 19 \text { Belçika, } \\
\% 17 \text { İtalya }\end{array}$ & $\% 13$ & $\begin{array}{l}\% 6 \text { Yunanistan, } \\
\text { Finlandiya }\end{array}$ \\
\hline Hoşgörü & $\begin{array}{c}\% 20 \text { Ingiltere, } \\
\% 15 \text { Fransa }\end{array}$ & $\% 13$ & $\begin{array}{c}\% 4 \text { Yunanistan, } \\
\% 6 \text { İsveç, Finlandiya }\end{array}$ \\
\hline $\begin{array}{l}\text { Diğer Kültürlere } \\
\text { Saygl }\end{array}$ & $\begin{array}{l}\text { \%19 Hollanda, } \\
\text { \%17 İngiltere, Fransa }\end{array}$ & $\% 13$ & $\begin{array}{c}\% 5 \text { Finlandiya } \\
\text { Avusturya }\end{array}$ \\
\hline Eşitlik & $\begin{array}{c}\% 28 \text { Finlandiya } \\
\text { \%26 İsvec }\end{array}$ & $\% 12$ & $\begin{array}{l}\text { \%9 Almanya } \\
\text { İtalya }\end{array}$ \\
\hline
\end{tabular}


Tablo 2.b (Devamı)

\begin{tabular}{|c|c|c|c|}
\hline Değerler & Yüksek Oran & $\begin{array}{l}15 \text { AB Üye Ülke } \\
\text { Ortalaması }\end{array}$ & Düşük Oran \\
\hline Din & $\begin{array}{c}\text { \%27 Yunanistan, } \\
\% 20 \text { İtalya }\end{array}$ & $\% 8$ & $\begin{array}{c}\% 2 \text { İsveç, \%3 } \\
\text { Danimarka, Fransa }\end{array}$ \\
\hline $\begin{array}{l}\text { Kendini } \\
\text { Gerçekleştirme }\end{array}$ & $\begin{array}{c}\% 8 \text { İlanda, } \\
\% 7 \text { Yunanistan, } \\
\text { Hollanda, Belçika }\end{array}$ & $\% 5$ & $\begin{array}{l}\text { \%3 İsveç, } \\
\text { Danimarka }\end{array}$ \\
\hline Fikrim Yok & $\begin{array}{c}\% 12 \text { Lüksembourg, } \\
\% 10 \text { Portekiz }\end{array}$ & $\% 5$ & $\begin{array}{l}\% 2 \text { Yunanistan, } \\
\text { Fransa }\end{array}$ \\
\hline $\begin{array}{l}\text { Bunlardan } \\
\text { Hiçbiri } \\
\end{array}$ & $\begin{array}{c}\% 5 \text { Portekiz, } \\
\% 4 \text { İtalya, Fransa }\end{array}$ & $\% 2$ & $\begin{array}{l}\% 0 \text { Finlandiya, } \\
\text { İsveç }\end{array}$ \\
\hline
\end{tabular}

Kaynakça: (Special Eurobarometer, 2004).

Tablo 2b'de görüldüğü gibi; “demokrasi” en önemli 5 değer arasında AB vatandaşlarının ülkelerini en iyi temsil ettiğine inandıkları bir kavram olarak görülmektedir. \%67'lik bir oranla Danimarka'da en yüksek yüzdeye ulaşırken, genel ortalama \%46'dır. "Barış" yine \%30'luk bir oranla ikinci sırada yer alırken, en yüksek değer \%62'lik bir oranla Yunanistan vatandaşları tarafından verilmiştir. Anketin 3. sıralamasında "insan hakları" ön plana çıkmıştır. Fransa \%54'lük bir oranla önde giderken, Portekiz \%21'lik bir oranla karşllık vermiştir. "Hukuk kuralları" ise genel AB ortalamasında \%32'lik bir orana ulaşmıştır. Bu konuda \%47'lik bir oranla Finlandiya önde giderken, en düşük orana Yunanistan ve Lüksembourg sahip olmuştur. "Insan yaşamına saygı"da ise genel $\mathrm{AB}$ ortalaması $\% 21$ 'dir. En yüksek orana \%18 ile Yunanistan ve Lüksembourg sahip olmuştur.

$\mathrm{AB}$ ile ilgili değerler sıralaması ise Tablo 2c'de görüldüğü gibidir. $\mathrm{AB}$ vatandaşları, "barış"1 AB'yi en iyi temsil eden değer olarak birinci sıraya koymuştur. Ortalama oran olarak \%38'e sahip olan "barış"ın en yüksek görüldügüu ülke \%56'lı oranla İsveç'tir. İkinci sırada "insan hakları" gelmektedir. Bu değere en yüksek oran \%39 ile İrlanda vatandaşlan tarafından verilmiştir. "Demokrasi" en yüksek orana, \%36 ile İspanyanın ulaştığı bir değer olarak 3. sırada yer almıştır. Burada dikkat çekici bir noktaya işaret etmek gerekmektedir. Bu değer $\mathrm{AB}$ vatandaşlarının kendi ülkelerini en iyi temsil eden değer olarak sorulduğunda "demokrasi" ilk sırada yer alırken, AB'yi temsil eden değer olarak sorulduğunda 3. sıraya gerilemiştir.

Araştırmanın diğer bir kısmında $\mathrm{AB}$ vatandaşlarının "Amerika Birleşik Devletleri'nin en iyi hangi değerlerle temsil edileceğini düşünüyorsunuz?" sorusuna verdikleri yanıt Tablo 3.2d'de görüldüğü gibidir. $15 \mathrm{AB}$ ülkesi değerlendirme yaparken; ABD'nin en önemli niteliğini \%24 oy oranıyla 
"Bireysel özgürlük" olarak görmüştür. Danimarka en yüksek değeri \%41 olarak verirken, Yunanistan'da bu oran \%11'lere düşmüştür. "Demokrasi”yi $\mathrm{AB}$ vatandaşları kendi ülkelerinin karakteristik özelliği olarak hayli yüksek bir oranla en ön siraya koyarken, bu durum $\mathrm{ABD}$ için İngiltere ve Danimarka'nın öncülüğünde 2. sırada yerini almıştır. "Hukuk kuralları" 3. sırada en önemli nitelik olarak görülmektedir. "Kendini gerçekleștirme" 4. sırada yer alırken dikkat çekici bir durum ortaya çıkmıştır; "Fikrim yok" ibaresi 5. sıraya yerleşirken, "insan hakları" daha önceki tablolarda ön sıralarda olan "barış" değeri, AB vatandaşları tarafından ABD'nin karakteristik özelliği olarak ancak 6. sırada yer alabilmiştir.

Tablo 2.c: AB Vatandaşlarının AB'yi En İyi Temsil Ettiğine İnandıkları Değerlerin Ülkelere Göre Yüzde Oranları

\begin{tabular}{|c|c|c|c|}
\hline Değerler & Yüksek Oran & $\begin{array}{l}15 \text { AB Üye Ülke } \\
\text { Ortalaması }\end{array}$ & Düşük Oran \\
\hline Barış & $\begin{array}{c}\text { \%57 İsveç, } \\
\% 50 \text { Yunanistan }\end{array}$ & $\% 38$ & $\begin{array}{c}\% 27 \text { İngiltere, } \% 32 \\
\text { İspanya, Portekiz }\end{array}$ \\
\hline İnsan Hakları & $\begin{array}{l}\text { \%39 Irlanda, Fransa, } \\
\text { Danimarka, Almanya }\end{array}$ & $\% 36$ & $\begin{array}{c}\text { \%25 Portekiz, } \\
\% 30 \text { İspanya }\end{array}$ \\
\hline Demokrasi & $\begin{array}{c}\text { \%36 İspanya, } \\
\% 34 \text { İsveç, Belçika, } \\
\text { Danimarka Almanya }\end{array}$ & $\% 30$ & $\begin{array}{c}\% 22 \text { Lüksemburg, \%23 } \\
\text { İngiltere }\end{array}$ \\
\hline \begin{tabular}{|l|} 
Hukuk \\
Kuralları \\
\end{tabular} & $\begin{array}{l}\% 37 \text { Hollanda, } \\
\% 32 \text { Finlandiya }\end{array}$ & $\% 23$ & \begin{tabular}{|c|}
$\% 14$ Lüksemburg, $\% 16$ \\
Portekiz, Fransa
\end{tabular} \\
\hline \begin{tabular}{|l} 
Diğer \\
Kültürlere \\
Sayg1 \\
\end{tabular} & $\begin{array}{l}\% 25 \text { Fransa, } \\
\% 22 \text { Finlandiya }\end{array}$ & $\% 19$ & $\begin{array}{l}\text { \%8 Avusturya, } \\
\text { \%9 İspanya }\end{array}$ \\
\hline $\begin{array}{l}\text { Insan Yaşamına } \\
\text { Sayg1 }\end{array}$ & $\begin{array}{c}\% 27 \text { İrlanda, } \% 21 \\
\text { İtalya, Lüksemburg, } \\
\text { Portekiz }\end{array}$ & $\% 17$ & $\begin{array}{l}\text { \%8 Hollanda, } \\
\text { \%9 Danimarka }\end{array}$ \\
\hline Fikrim Yok & $\begin{array}{l}\% 23 \text { İngiltere, } \\
\% 20 \text { Portekiz }\end{array}$ & $\% 16$ & $\begin{array}{l}\% 9 \text { Yunanistan, } \\
\% 11 \text { Italya }\end{array}$ \\
\hline Dayanışma & $\begin{array}{c}\text { \%20 Belçika, } \\
\% 17 \text { İsveç, Portekiz, } \\
\text { Fransa, Almanya }\end{array}$ & $\% 15$ & $\begin{array}{l}\text { \%9 Finlandiya, } \\
\text { \%11 Danimarka }\end{array}$ \\
\hline \begin{tabular}{|l|} 
Bireysel \\
Özgürlük
\end{tabular} & $\begin{array}{l}\% 21 \text { Avusturya } \\
\% 18 \text { İlanda }\end{array}$ & $\% 13$ & $\begin{array}{l}\text { \%7 Hollanda, } \\
\text { \%8 Danimarka }\end{array}$ \\
\hline Eşitlik & $\begin{array}{l}\text { \%23 İrlanda, } \\
\text { \%16 İngiltere, } \\
\text { Yunanistan }\end{array}$ & $\% 13$ & $\begin{array}{l}\text { \%8 İsveç, } \\
\% 9 \text { Fransa }\end{array}$ \\
\hline Hoşgörü & $\begin{array}{l}\% 13 \text { Belçika, \%12 } \\
\text { Almanya, İspanya }\end{array}$ & $\% 10$ & $\begin{array}{l}\text { \%3 Yunanistan, } \\
\% 5 \text { İsveç }\end{array}$ \\
\hline $\begin{array}{l}\text { Kendini } \\
\text { Gerçekleştirme }\end{array}$ & $\begin{array}{l}\% 12 \text { Yunanistan, } \\
\% 6 \text { Avusturya }\end{array}$ & $\% 5$ & $\begin{array}{l}\text { \%3 Portekiz, İtalya, } \\
\text { Lüksemburg }\end{array}$ \\
\hline
\end{tabular}




\begin{tabular}{|l|c|c|c|}
\hline \multicolumn{4}{|c|}{ Tablo 2.c (Devamı) } \\
\hline Değerler & Yüksek Oran & $\begin{array}{c}\text { 15 AB Üye Ülke } \\
\text { Ortalaması }\end{array}$ & Düşük Oran \\
\hline Bunlardan & $\begin{array}{c}\text { \%6 Fransa, } \\
\text { Danimarka }\end{array}$ & $\% 3$ & $\% 0$ İrlanda \\
\hline Hiçbiri & $\begin{array}{c}\text { \%5 Yunanistan, } \\
\text { Avusturya, \%4 } \\
\text { İngiltere, İsveç }\end{array}$ & $\% 3$ & $\begin{array}{c}\text { \%2 İspanya, Belçika, } \\
\text { Fransa, Lüksemburg } \\
\text { Danimarka, Finlandiya }\end{array}$ \\
\hline
\end{tabular}

Kaynak: (Special Eurobarometer,2004)

Tablo 2.d: AB Vatandaşlarının ABD'yi En İyi Temsil Ettiğine İnandıkları Değerlerin Ülkelere Göre Yüzde Oranları

\begin{tabular}{|c|c|c|c|}
\hline Değerler & Yüksek Oran & $\begin{array}{c}15 \text { AB Üye Ülke } \\
\text { Ortalaması }\end{array}$ & Düşük Oran \\
\hline $\begin{array}{l}\text { Bireysel } \\
\text { Bağımsızlık }\end{array}$ & $\begin{array}{l}\text { \%41 Danimarka, } \\
\text { \%40 İsveç }\end{array}$ & $\% 24$ & $\begin{array}{l}\text { \%11 Yunanistan, } \\
\text { \%13 Portekiz }\end{array}$ \\
\hline Demokrasi & $\begin{array}{l}\% 32 \text { İngiltere, } \\
\% 28 \text { Hollanda }\end{array}$ & $\% 23$ & $\begin{array}{l}\text { \%11 Yunanistan, } \\
\text { \%14 Lüksemburg }\end{array}$ \\
\hline Hukuk Kuralları & $\begin{array}{l}\% 33 \text { Hollanda, } \\
\% 31 \text { İngiltere }\end{array}$ & $\% 21$ & $\begin{array}{l}\text { \%7 Yunanistan, } \\
\text { \%14 Portekiz }\end{array}$ \\
\hline $\begin{array}{l}\text { Kendini } \\
\text { Gerçekleștirme }\end{array}$ & $\begin{array}{c}\text { \%32 İsveç, } \\
\text { \%31 Finlandiya }\end{array}$ & $\% 19$ & $\begin{array}{l}\text { \%11 Belçika, } \\
\text { İspanya }\end{array}$ \\
\hline Fikrim Yok & $\begin{array}{c}\% 30 \text { Lüksemburg, } \\
\% 29 \text { Portekiz }\end{array}$ & $\% 18$ & $\begin{array}{l}\text { \%13 İtalya, } \\
\text { Danimarka }\end{array}$ \\
\hline İnsan Hakları & $\begin{array}{c}\text { \%28 İrlanda, } \\
\% 23 \text { Avusturya }\end{array}$ & $\% 17$ & $\begin{array}{l}\text { \%11 Yunanistan, } \\
\text { \%12 İspanya }\end{array}$ \\
\hline \begin{tabular}{|l} 
Bunlardan \\
Hiçbiri \\
\end{tabular} & $\begin{array}{c}\text { \%24 Yunanistan, } \\
\% 19 \text { Fransa }\end{array}$ & $\% 12$ & $\begin{array}{l}\text { \%3 İrlanda, } \\
\text { İngiltere }\end{array}$ \\
\hline $\begin{array}{l}\text { İnsan Yaşamına } \\
\text { Saygı }\end{array}$ & $\begin{array}{c}\% 21 \text { İrlanda, \%16 } \\
\text { İngiltere, \%14 } \\
\text { İtalya, Avusturya }\end{array}$ & $\% 11$ & $\begin{array}{c}\% 5 \text { Hollanda, } \% 6 \\
\text { Danimarka, } \\
\text { Finlandiya } \\
\end{array}$ \\
\hline $\begin{array}{l}\text { Diğer Kültürlere } \\
\text { Sayg1 }\end{array}$ & $\begin{array}{l}\text { \%14 İrlanda } \\
\text { İtalya }\end{array}$ & $\% 9$ & $\begin{array}{l}\% 4 \text { Hollanda, } \\
\% 6 \text { Finlandiya, } \\
\text { İspanya }\end{array}$ \\
\hline Hoşgörü & $\begin{array}{c}\% 12 \text { İlanda, } \\
\text { Avusturya, Almanya }\end{array}$ & $\% 9$ & $\begin{array}{c}\text { \%4 Hollanda, } \\
\text { \%5 İsveç }\end{array}$ \\
\hline Din & $\begin{array}{c}\% 21 \text { Finlandiya, \%17 } \\
\text { İsveç, Hollanda }\end{array}$ & $\% 8$ & $\begin{array}{l}\text { \%2 Yunanistan, } \\
\% 3 \text { İspanya }\end{array}$ \\
\hline Eşitlik & $\begin{array}{l}\% 15 \text { İrlanda, } \\
\% 13 \text { İngiltere }\end{array}$ & $\% 8$ & $\begin{array}{l}\text { \%4 Fransa, İsveç, } \\
\text { Lüksemburg }\end{array}$ \\
\hline Dayanışma & $\begin{array}{l}\text { \%12 Belçika, } \\
\text { \%11 İrlanda }\end{array}$ & $\% 7$ & $\begin{array}{c}\text { \%3 Yunanistan, } \\
\text { İspanya }\end{array}$ \\
\hline
\end{tabular}

Kaynak: (Special Eurobarometer, 2004) 
Avrupa vatandaşlarının Arap ülkeleriyle ilgili değerlendirmelerine bakıldığında, Arap dünyasını en iyi temsil eden değer olarak "din" ibaresini düşündükleri görülmektedir. \%45'lik genel ortalamayla bu oran en yüksek değere \%65 ile Finlandiyalılar arasında ulaşmıştır. Yine dikkat çekici bir biçimde "fikrim yok" ibaresinin \%24'lük bir oranla 2. sıraya yerleşmesi, AB vatandaşlarının Arap dünyası hakkında ne kadar az bilgiye sahip olduklarının bir göstergesi olarak görülebilir.

Tablo 2.e: AB Vatandaşlarının Arap Dünyasını En İyi Temsil Ettiğine İnandıkları Değerlerin Ülkelere Göre Yüzde Oranları

\begin{tabular}{|c|c|c|c|}
\hline Değerler & Yüksek Oran & $\begin{array}{c}15 \text { AB Üye Ülke } \\
\text { Ortalaması }\end{array}$ & Düşük Oran \\
\hline Din & $\begin{array}{c}\% 65 \text { Finlandiya, } \\
\% 64 \text { Hollanda }\end{array}$ & $\% 45$ & $\begin{array}{c}\text { \%26 İrlanda, } \\
\text { \%29 Lüksemburg }\end{array}$ \\
\hline Fikrim Yok & $\begin{array}{l}\text { \%35 Lüksemburg, \%33 } \\
\text { Portekiz, \%32 İspanya }\end{array}$ & $\% 24$ & $\begin{array}{c}\% 17 \text { Hollanda, \%18 } \\
\text { Finlandiya, \%19 Fransa }\end{array}$ \\
\hline $\begin{array}{l}\text { Bunlardan } \\
\text { Hiçbiri }\end{array}$ & \%17 İtalya, İspanya & $\% 13$ & $\begin{array}{c}\text { \%4 İngiltere, } \\
\% 6 \text { İrlanda }\end{array}$ \\
\hline $\begin{array}{l}\text { Hukuk } \\
\text { Kuralları } \\
\end{array}$ & $\begin{array}{l}\% 26 \text { Hollanda, İngiltere, } \\
\% 20 \text { İrlanda }\end{array}$ & $\% 11$ & $\begin{array}{c}\% 3 \text { Portekiz,\%4 } \\
\text { İspanya, Yunanistan }\end{array}$ \\
\hline Barış & $\begin{array}{l}\% 23 \text { İrlanda, } \\
\% 18 \text { İngiltere }\end{array}$ & $\% 11$ & $\begin{array}{c}\% 4 \text { Danimarka, } \\
\% 5 \text { Hollanda }\end{array}$ \\
\hline $\begin{array}{l}\text { Insan } \\
\text { Yaşamına } \\
\text { Saygi }\end{array}$ & $\begin{array}{l}\% 18 \text { İrlanda, } \\
\% 15 \text { İngiltere }\end{array}$ & $\% 9$ & $\begin{array}{l}\% 4 \text { Danimarka, } \% 5 \\
\text { Fransa, Hollanda }\end{array}$ \\
\hline İnsan Haklan & $\begin{array}{l}\% 16 \text { Irlanda, } \\
\% 15 \text { Avusturya }\end{array}$ & $\% 8$ & $\begin{array}{l}\% 3 \text { Danimarka, } \% 4 \\
\text { Hollanda, Portekiz }\end{array}$ \\
\hline $\begin{array}{l}\text { Diğer } \\
\text { Kültürlere } \\
\text { Sayg1 }\end{array}$ & $\begin{array}{l}\% 13 \text { İrlanda, } \\
\% 12 \text { İngiltere }\end{array}$ & $\% 8$ & $\begin{array}{c}\% 4 \text { Danimarka, \%5 } \\
\text { Yunanistan, Finlandiya }\end{array}$ \\
\hline Dayanışma & $\begin{array}{c}\% 15 \text { Yunanistan, \%14 } \\
\text { Belçika, \%13 Fransa }\end{array}$ & $\% 7$ & $\begin{array}{c}\% 3 \text { İspanya, \%4 Dan., } \\
\text { Portekiz, İsveç }\end{array}$ \\
\hline $\begin{array}{l}\text { Kendini } \\
\text { Gerçekleştirme }\end{array}$ & $\begin{array}{l}\text { \%17 Danimarka, } \\
\% 11 \text { İrlanda, Finlandiya }\end{array}$ & $\% 7$ & $\begin{array}{l}\% 3 \text { Yunanistan, } \\
\text { Fransa, İspanya } \\
\end{array}$ \\
\hline $\begin{array}{l}\text { Bireysel } \\
\text { Özgürlük }\end{array}$ & $\begin{array}{l}\text { \%14 İrlanda, } \\
\% 11 \text { Avusturya }\end{array}$ & $\% 6$ & $\begin{array}{c}\% 2 \text { Finlandiya, } \\
\% 3 \text { Portekiz }\end{array}$ \\
\hline Hoşgörü & $\begin{array}{c}\% 10 \text { İrlanda, \%8 İng., } \\
\text { Avusturya, Belçika }\end{array}$ & $\% 5$ & $\% 2$ Finlandiya, İsveç \\
\hline Demokrasi & \%10 İrlanda, \%8 İsveç & $\% 4$ & $\begin{array}{c}\% 1 \text { Hollanda,\%2 } \\
\text { Danimarka, Finlandiya }\end{array}$ \\
\hline Eşitlik & $\begin{array}{c}\% 10 \text { İrlanda, } \% 5 \text { Belçika, } \\
\text { Almanya, İtalya, } \\
\text { Avusturya, Portekiz }\end{array}$ & & $\begin{array}{c}\% 1 \text { Danimarka, \%3 } \\
\text { İsveç, Finlandiya }\end{array}$ \\
\hline
\end{tabular}

Kaynak: (Special Eurobarometer, 2004). 
"Bunlardan hiçbiri" ibaresi 3. sırada yer alırken, "hukuk kuralları" ve "barış" 4. sırayı paylaşmıştır. "İnsan hakları" ve "diğer kültürlere saygı" 7. sırayı paylaşırken, daha önceki tablolardaki değerlerden hayli düşük bir oranla "demokrasi", son sırayı "eşitlik" ile paylaşmıştır.

\section{Avrupa Birliği Vatandaşlarının Farklı Konulara İlişkin Tutumlarmm Analizi}

$\mathrm{Bu}$ araştırmanın konusu, 15 üyeli $\mathrm{AB}$ vatandaşlarına devlet müdahalesi, göçmenler, çevre vb. konulara ilişkin olarak sorulan soruların değerlendirilmesiyle ilgilidir. Sorular Tablo 3.a'da görülen 5 seçenek çerçevesinde değerlendirilmiştir. Bu tabloda devletin kişilerin yaşamına müdahalesi konusunda ülkelere göre vatandaşların görüşleri yüzde değer olarak sıralanmıştır. Tablo 3.a'da görüldüğü gibi; AB ortalamasının \%64'ü devletin vatandaşlarının yaşamlarına müdahale ettiği konusunda görüşlerini ileri sürmüşlerdir. Bu etkiyi en fazla hisseden ülkeler; \%69 ile Belçika, \%68 ile oranla Fransa, \%66 ile Almanya ve İngiltere olurken, 5. sırada \%65 ile İtalya vatandaşları olmuştur. Bu etkinin en az hissedildiği ülke ise \%38 ile Lüksemburg olarak yer almıştır.

Tablo 3.a: "Devlet Yaşantımıza Çok Müdahale Ediyor (\%)

\begin{tabular}{|l|c|c|c|c|c|}
\hline \multicolumn{1}{|c|}{ Ülkeler } & $\mathbf{A}^{*}$ & $\mathbf{B}^{*}$ & $\mathbf{C}^{*}$ & $\mathbf{D}^{*}$ & $\mathbf{E}^{*}$ \\
\hline Belçika & 29 & 40 & 22 & 4 & 6 \\
\hline Danimarka & 15 & 40 & 31 & 9 & 5 \\
\hline Almanya & 23 & 43 & 24 & 6 & 5 \\
\hline Yunanistan & 37 & 43 & 13 & 5 & 3 \\
\hline Ispanya & 19 & 38 & 24 & 9 & 10 \\
\hline Fransa & 26 & 42 & 24 & 5 & 4 \\
\hline Irlanda & 23 & 37 & 25 & 6 & 10 \\
\hline İtalya & 21 & 44 & 20 & 9 & 6 \\
\hline Lüksemburg & 16 & 22 & 39 & 19 & 3 \\
\hline Hollanda & 17 & 39 & 35 & 5 & 4 \\
\hline Avusturya & 24 & 34 & 32 & 4 & 7 \\
\hline Portekiz & 17 & 50 & 24 & 2 & 8 \\
\hline Finlandiya & 10 & 36 & 44 & 7 & 4 \\
\hline İsveç & 24 & 39 & 29 & 5 & 4 \\
\hline İngiltere & 25 & 41 & 23 & 3 & 8 \\
\hline 15- AB & 23 & 41 & 24 & 6 & 6 \\
\hline * A=Tamamen Katıliyorum; B=Katllyorum; C=Katılmıorum; D= Tamamen \\
Katılmiyorum; F= Fikrim Yok.
\end{tabular}

Kaynakça: (Special Eurobarometer, 2004). 
Bir diğer araştırma konusu ise, AB vatandaşlarının daha az bireysel özgürlüğe rağmen daha fazla eşitlik ve adalet talepleri ile ilgili araştırmadır. Tablo 3.b'de bu konuya yönelik $\mathrm{AB}$ vatandaşlarının görüşleri ülkeler bazında değerlendirilmektedir. Tablo 3.b'de görüldüğü gibi; bu görüşe $\mathrm{AB}$ vatandaşların \%60'ı katılmaktadır. Bu görüşe katılımın en yüksek olduğu ülke \%81 oranıyla Portekiz olmuştur. Bu ülkeyi sırasıyla Yunanistan ve Fransa izlemiştir. Bu fikre en az katılan ülke ise \%47'lik oranla Danimarka olmuştur.

Tablo 3.b: "Daha Az Bireysel Özgürlük Pahasma Daha Çok Eşitlik ve Adalete îhtiyacımız var" (\%)

\begin{tabular}{|l|c|c|c|c|c|}
\hline \multicolumn{1}{|c|}{ Ülkeler } & $\mathbf{A}^{*}$ & $\mathbf{B}^{*}$ & $\mathbf{C}^{*}$ & $\mathbf{D}^{*}$ & $\mathbf{E}^{*}$ \\
\hline Belçika & 21 & 38 & 27 & 5 & 9 \\
\hline Danimarka & 11 & 36 & 37 & 9 & 8 \\
\hline Almanya & 22 & 36 & 26 & 9 & 8 \\
\hline Yunanistan & 36 & 37 & 17 & 7 & 4 \\
\hline İspanya & 21 & 34 & 22 & 12 & 12 \\
\hline Fransa & 22 & 43 & 22 & 7 & 6 \\
\hline İrlanda & 20 & 37 & 21 & 9 & 13 \\
\hline İtalya & 29 & 44 & 16 & 7 & 4 \\
\hline Lüksemburg & 26 & 35 & 24 & 10 & 5 \\
\hline Hollanda & 14 & 35 & 38 & 6 & 7 \\
\hline Avusturya & 20 & 34 & 30 & 7 & 9 \\
\hline Portekiz & 29 & 52 & 11 & 1 & 6 \\
\hline Finlandya & 12 & 39 & 33 & 7 & 9 \\
\hline İsvec & 16 & 36 & 34 & 8 & 7 \\
\hline Ingiltere & 20 & 34 & 26 & 8 & 12 \\
\hline 15-AB & 22 & 38 & 24 & 8 & 8 \\
\hline$*$ A=Tamamen Katıliyorum; B=Katılıorum; C=Katılmiyorum; D= Tamamen \\
\hline Katılmyorum; F= Fikrim Yok.
\end{tabular}

Kaynakça: (Special Eurobarometer, 2004). 
Tablo 3.c: "Göçmenler Ülkemize Pek Çok Katkı Sağlamaktadır” $(\%)$

\begin{tabular}{|c|c|c|c|c|c|}
\hline Ülkeler & $\mathbf{A}^{*}$ & B* & $C^{*}$ & D* & $\mathbf{E}^{*}$ \\
\hline Belçika & 5 & 19 & 31 & 35 & 10 \\
\hline Danimarka & 6 & 32 & 34 & 18 & 10 \\
\hline Almanya & 4 & 24 & 35 & 24 & 14 \\
\hline Yunanistan & 11 & 28 & 29 & 29 & 3 \\
\hline İspanya & 14 & 27 & 26 & 17 & 17 \\
\hline Fransa & 9 & 30 & 28 & 22 & 12 \\
\hline Irlanda & 7 & 32 & 29 & 17 & 15 \\
\hline İtalya & 9 & 35 & 29 & 19 & 8 \\
\hline Lüksemburg & 19 & 33 & 26 & 15 & 7 \\
\hline Hollanda & 4 & 36 & 36 & 16 & 8 \\
\hline Avusturya & 6 & 30 & 35 & 20 & 9 \\
\hline Portekiz & 11 & 53 & 23 & 3 & 10 \\
\hline Finlandya & 13 & 44 & 28 & 10 & 5 \\
\hline İsveç & 20 & 45 & 22 & 9 & 5 \\
\hline İngiltere & 10 & 22 & 28 & 31 & 9 \\
\hline $15-\mathrm{AB}$ & 9 & 29 & 30 & 22 & 11 \\
\hline
\end{tabular}

Kaynak: (Special Eurobarometer, 2004).

AB vatandaşlarına göçmenlerin geldiği ülkeye katkı yapıp yapmadıklarına ilişkin görüşleri de sorulmaktadır. Konuyla ilgili değerlendirmeler Tablo 3.c'de görüldüğü gibidir. Bu konuyla ilgili olarak genel ortalamaya bakıldığında, \%38'lik kısmı bu ifadeye katılmakla birlikte, katılmayanların oranı \%52'lik bir oranla ön plana çıkmıştır. Tablo 3.c'de görüldüğg̈ gibi, bu görüşe katılım oranları diğer konularla karşılaştırıldığında düşük seviyelerde bulunmaktadır. Bu görüşe en çok destek veren ülkeler \%65 ile İsveç, \%64 ile Portekiz, \%57 ile Finlandiya olmuştur. En az destek veren ülke ise \%24 ile Belçika olmuştur.

\section{Avrupa Birliği'nin Gelişiminde Genç Avrupalıların İlgi ve Beklentilerine Yönelik Analizler}

9 Mayıs-14 Haziran 2005 tarihleri arasında, Avrupa Birliği üye ülkelerinin gençleri arasında; gençlerin $A B$ ile ilgili beklenti ve ilgileri üzerine bir araştırma yapılmıştır. Gençlerin AB'nin gelişimine katkılarının gerekli olduğu konusundan yola çıkılarak yapılan bu araştırmada; 3 kategori ve her kategori içinde 2 grup oluşturulmuştur. Bu gruplar; 1. Genç vatandaşlar ve diğer vatandaşlar, 2. 15-19 yaş arası, 20-24 yaş arası gençler 
3. 15 üyeli $A B$ gençleri, 10 yeni üye ülke gençleri'dir. Burada $A B$ ile ilgili çeşitli sorular sorularak verilen cevaplara karşılık yüzde oranlar belirlenmiştir (Standart Eurobarometer, 2005).

"Kişisel olarak $\mathrm{AB}$ size göre ne anlama gelmektedir? Eğitim ve her yerde çalışmak için özgürlüğe yolculuk mudur?" sorularına tüm $\mathrm{AB}$ vatandaşları \%52 oranında "evet" $\mathrm{AB}$ 'nin anlamı özgürlüğe bir yolculuktur" derken, genç vatandaşlar ise bu oranı artırarak \%62 oranında bu soruya evet karşılı̆̆ını vermiştir. İkinci kategoride 15-19 yaş arası gençlerin bu soruya yanıtı \%64 ile "evet" çımış, 20-24 yaş arası gençler ise \%61 ile "evet" demiştir. Üçüncü kategoride ise, 15 üyeli $\mathrm{AB}$ vatandaşları $\% 59$ oy oranıyla görüşlerini ifade ederken bu oran en yüksek seviyeye, 10 yeni üye ülkede \%76 oranına ulaşılmıştır. “AB'nin siyasi birliğe doğru ilerlemesine karşı mısınız?" sorusuna yönelik olarak oylamaya katılan $A B$ vatandaşları $\% 58$ 'lik bir oranda "evet" derken, genç vatandaşlar \%65 seviyesine çıkarak görüşlerini ifade etmişlerdir. İkinci kategoride 15-19 yaş arası gençlerin oranı \%70'e çıkarken, 20-24 yaş arası gençlerin oy oranı ise \%62'yi bulmuştur. Üçüncü kategoride, 15 üyeli $\mathrm{AB}$ gençleri \%62 ile evet derken, en yüksek oran $\% 77$ ile yine 10 yeni üyeden gelmiştir. Bu sonuca göre $A B$ 'nin siyasi birliğe doğru gidişini gençlerin yarısından çoğunun istemediği görülmektedir. "Önümüzdeki 5 yıllık zaman dilimi içinde $\mathrm{AB}$ 'nin günlük hayatınızda daha fazla bir rol oynamasını ister misiniz?" sorusuna tüm $\mathrm{AB}$ vatandaşları \%49 ile "evet" derken, genç vatandaşlar \%55 oranında "evet" oyu vermişlerdir. 15-19 yaş arası ve 20-24 yaş arası gençler aynı oranda $\% 55$ 'lik bir oranla "evet" diyerek görüşlerini ifade etmişlerdir. Üçüncü kategoride 15 üyeli $\mathrm{AB}$ gençleri $\% 52$ 'lik bir oranla katılırlarken, en yüksek oran yine \%67 ile 10 yeni ülke gençlerinden gelmiştir. "AB'deki demokrasi uygulamasından memnun musunuz?" sorusuna $\mathrm{AB}$ 'ye üye ülke vatandaşları \%49'luk bir oranla, yani yarıdan daha az bir oranla "evet" demiştir. Genç vatandaşlarda ise bu oran \%55'e çıkmıştır. İkinci kategoride; 15-19 yaş arası gençler $\% 58$ oy oranını gösterirken, 20-24 yaş sınırında $\% 6$ 'lık bir düşü̧ş yaşanarak \%52'de kalmıştır. Üçüncü kategoride ise, 15 üyeli $A B$ gençleri \%53'lük bir orana sahip olurken, 10 yeni ülke gençlerinde bu oran \%62'ye çıkmıştır. "AB'de benim de sesim duyulsun diyor musunuz?" sorusuna, 10 genç Avrupalıdan sadece 4'ü AB'de sesini duyurmak istemektedir. Birinci kategoride tüm vatandaşların \%38'i "evet" derken, genç vatandaşlar \%39'luk bir oranla evet demişlerdir. İkinci kategoride ise; $15-19$ yaş arası gençlerin oy oranı ise \%37, 20-24 yaş arası gençlerin oranı ise \%40'tır. Üçüncü kategoriye bakıldığında; 15 üyeli $\mathrm{AB}$ gençleri \%38'de kalırken, 10 yeni ülke gençleri ise yine en yüksek oran olan $\% 41$ oy oranıyla \%50'nin altında kalmışlardır. Gençlere kaygıları sorulduğunda çok açık bir 
biçimde işsizliğin ilk sıralarda yer aldığı görülmektedir. Onlara göre işsizlikle mücadele Birliğin çözmesi gereken en önemli önceliği olmalıdır. Özellikle yeni üye olan 10 ülke gençlerinde bu düşünce daha fazla öne çıkmaktadır. "Size göre AB'nin öncelik vermesi gereken 3 faaliyeti ne olmalıdır?" sorusuna verilen yanıtlar Tablo 4'te görüldügü gibidir.

Tablo 4: "Size Göre AB'nin Öncelik Vermesi Gereken 3 Faaliyeti Ne Olmalıdır?"

\begin{tabular}{|l|c|c|c|}
\hline \multicolumn{1}{|c|}{ Gruplar } & $\begin{array}{c}\text { İşsizlikle } \\
\text { Mücadele }\end{array}$ & $\begin{array}{c}\text { Yoksulluk ve } \\
\text { Sosyal Dışlamayla } \\
\text { Mücadele }\end{array}$ & $\begin{array}{c}\text { Avrupa'da Barış } \\
\text { ve Güvenliğin } \\
\text { Sürdürülmesi }\end{array}$ \\
\hline Tüm AB Vatandaşları & $\% 47$ & $\% 44$ & $\% 31$ \\
\hline Genç Vatandaşlar & $\% 52$ & $\% 45$ & $\% 30$ \\
\hline $\begin{array}{l}15-19 \text { Yaş Arası } \\
\text { Gençler }\end{array}$ & $\% 51$ & $\% 44$ & $\% 35$ \\
\hline $\begin{array}{l}\text { 20-24 Yaş Arası } \\
\text { Gençler }\end{array}$ & $\% 53$ & $\% 47$ & $\% 26$ \\
\hline 15 Üyeli AB Gençleri & $\% 48$ & $\% 41$ & $\% 31$ \\
\hline $\begin{array}{l}\text { 10 Yeni Üye Ülke } \\
\text { Gençleri }\end{array}$ & $\% 68$ & $\% 60$ & $\% 27$ \\
\hline
\end{tabular}

Kaynak: (Standart Eurobarometer, 2005)

Görüldüğü gibi "işsizlikle mücadele"den sonra genç Avrupalılar için "yoksullukla mücadele ve sosyal dışlanma" AB'nin faaliyetleri içinde ikinci önceliği oluşturmaktadır. Üçüncü öncelik ise, görüldüğü gibi "barış ve güvenliğin korunması" konusudur. $\mathrm{AB}$ ile ilgili olarak gençlerin olumlu yaklaşımlarına rağmen, Avrupa'nın yapılanmasında gençler arasında AB içinde diğer ülkelerden iş için gelen kişilerin daha az ücretle çalışıp onların işlerini kaybetmelerine neden olmaları korkusu yer almaktadır. Bununla ilgili olarak sorulan "diğer üye ülkelerden gelen çalışanlarla ilgili korkularınız var mıdır?" sorusuna verilen yanıtların oranı şu şekildedir; Birinci kategoride tüm $\mathrm{AB}$ vatandaşlarının verdiği "evet" yanıtlarının oranı yüksek bir seviye olup \% 73'tür. Genç vatandaşların yanıtı ise \%68'lik bir orandadır. İkinci kategoride 15-19 yaş arası vatandaşların oranı \%64'e ulaşırken, 20-24 yaş sınırına gelindiğinde bu oran \%71'e çıkmaktadır. 15 üyeli $\mathrm{AB}$ gençlerinde bu oran $\% 71$ olurken, 10 yeni üye ülke gençlerinde "evet" oranı diğer gruplara oranla daha düşük oran olan \%57'ye inmiştir. Görüldüğü gibi diğer üye ülkelerden işçi transferi konusunda 3 gençten 2'si korku yaşamaktadır. 


\section{i. Genç Avrupalıların Aktif Vatandaşlığa Bakışı}

Avrupa Birliği projeleri içinde gençlerin politikaya ve çeşitli örgütlere aktif katılımının sağlanmasının, gençlerin kimliklerinin, ilgilerinin anlaşılmasının gerekli olduğu düşünülmekte; bu doğrultuda çalışmalar yapılmaktadır. En son yapılan Avrupa Parlamentosu seçimlerinde bu açıdan hayal kırıklığı yaşanmıştır. 18-24 yaş arası Avrupa gencinin sadece 1/3'ü bu seçimlere katılım göstermiştir. Bu başlık altındaki sorular, gençlerin aktif katılımı konusunda düşüncelerini öğrenmeye yönelik olarak yer almaktadır (Standart Eurobarometer, 2005).

"Mevcut siyasi sorunların ne şekilde gittiği ile ilgileniyorum" ifadesine yönelik olarak; birinci kategorideki tüm $\mathrm{AB}$ vatandaşları \%67 oy oranıyla "evet" karşılığını vermiştir. Genç vatandaşlar ise daha düşük bir oranda (\%55) bu soruya "evet" demiştir. İkinci kategoride 15-19 yaş arası gençlerde bu oran \%48'e düşerken, 20-24 yaş arası gençlerde ise \%61'e yükselmiştir. Üçüncü kategoride 15 üyeli $\mathrm{AB}$ vatandaşlarında oran $\% 57$ olurken en düşük seviyeye 10 yeni ülke gençlerinde inilmiştir.

"Mevcut siyasi sorunlardan yeteri kadar haberdar olduğuma inanıyorum" ifadesine tüm $\mathrm{AB}$ vatandaşlarından alınan yanıtların oranı $\% 58$ 'dir. Genç vatandaşlar bu konuda daha düşük bir oranla (\%47) cevap vermişlerdir. İkinci kategoride 15-19 yaş arası olan gençlerin "evet" oranı \%44'e düşmüş, 20-24 yaş arası gençler ise \%50'lik bir oranla "evet" demiştir. Üçüncü kategoride 15 üyeli $A B$ gençlerinin bu ifadeye katılım oranı \%48'de seyrederken 10 yeni üye ülke gençleri de \%44'de kalmıştır.

“Avrupa'ya gönülden bağlı mısınız?” sorusuna Avrupalı gençlerin 2/3’ü olumlu yanıt vermiştir. Birinci kategoride tüm $\mathrm{AB}$ vatandaşları \%66 ile karşılık vermişlerdir. Gençlerde ise bu oran 1 puan aşağı inerek \%65 seviyesine inmiştir. İkinci kategoride 15-19 yaş arası gençlerde bu oran 2 puan artarak \%67'ye yükselmiştir. 20-24 yaş arası gençler ise \%64 seviyesindedir. Üçüncü kategoride ise 15 üye ülke vatandaşının \%62'si bu soruya olumlu yanıt vermiştir. 10 üye ise diğer gruplara göre yaklaşık \% 10'luk bir farkla (\%78) "evet" demiştir.

Kendini ne oranda Avrupalı hissediyorsun?" sorusuna yönelik cevapların oranı şu biçimdedir; Birinci kategoride tüm AB vatandaşları \%54 gibi bir oranla "evet" olarak karşılık vermiştir. Bu soruda "Avrupalılık ve milliyet" düşüncesi bir arada yer almaktadır. Sadece "Avrupalı hissetme" sorusu buna eklendiğinde \%3'lük bir artışla \%57 oranına ulaşmıştır. Yine 
genç vatandaşlar; \%58 oranında yanıt verirken "Avrupalı hissetme" sorusuyla birlikte \%3 puanlık artış göstererek \%61'e ulaşmıştır. 15-19 yaş arası gençler için ilk sorunun oranı $\% 56$, ikinci soru eklenince $\% 60$ olmuştur. 20-24 yaş arası bu oran \%59 artış oranıly birlikte \%61 olarak görülmektedir. 15 üyeli $\mathrm{AB}$ gençlerinde bu oran sırasıyla, $\% 58$ ve $\% 61$ 'dir. En yüksek oran yine 10 yeni ülke vatandaşından gelerek sırasıyla $\% 60$ ve \%61'dir. Sonuçlara genel olarak bakıldığında, gençlerin AB'nin geleceği hakkında iyimser olduğu söylenebilir. 15-24 yaş arası gençlerin \%63'ü AB'nin iyi bir şey olduğunu, \%67'si ülkelerinin Birliğe üyeliğinden dolayı pek çok yarar sağladığını, \%56'sı ise AB'nin pozitif bir imajının olduğunu belirtmiştir. Gençler arasında üniversitede okumakta olanların Avrupa Birliği'ne her konuda daha yüksek bir oranda destek gösterdikleri görülmektedir. Örneğin, AB'nin genişlemesine bu kesim bugün \%59 destek verirken, okulu erken terk etmiş gençler ve 55 yaş üstü kişilerde bu destek \% 35-38 gibi bir düzeydedir. (Standard Eurobarometer, 2006)

\section{Avrupa'nın Geleceğine Yönelik Araştırma Sonuçları}

Genel olarak bakıldığında, halkın ekonomik ve sosyal anlamda geleceğe dair karamsar bir hava içinde olması, Avrupa'nın geleceğinin nasıl bir temel üzerine inşa edilmesi gerektiği sorusunu gündeme getirmektedir. Bu araştırmada, Avrupa vatandaşlarının beklentileri ve AB'nin geleceğini en iyi biçimde sağlamanın yolu araştırılmaktadır. Bu çerçevede AB'nin geleceğini dolaylı ve doğrudan etkileyecek iki faktör söz konusudur. Bunlar; genişleme ve küreselleşmedir (Special Eurobarometer, 2006). AB vatandaşlarının hem kendi ülkelerinin hem de Birlik düzeyinde yaşanan siyasi sorunlardan haberdar olup olmadıklanını anlamak; gerek kendi ülkelerinin gerekse AB yönetiminin nasıl bir yöne doğru gittiğini bilmek açısından önem taşımaktadır. Avrupa düzeyinde yapılan seçimlere bakıldığında, ülke düzeyinde yapılan seçimlere katılım oranı açısından gözle görülür biçimde farklılıklar yaşanması vatandaşların ilgisinin ne tarafa yöneldiğine dair ip uçları vermektedir. (Special Eurobarometer, 2006). Vatandaşlara sorulan "ulusal düzeydeki sorunlarla mı, yoksa Birlik düzeyindeki meselelerle mi daha çok ilgilenirsiniz?" soruya ankete katılan vatandaşların \%63'ü kendi ülkelerinin siyasi sorunları ile ilgilendikleri, \%37'si ise Avrupa düzeyindeki sorunlara daha duyarlı oldukları yönünde görüş bildirmişlerdir.

Bu konuyla ilgili olarak; "arkadaş veya akrabalarınızla bir araya geldiğinizde; ulusal ve AB ile ilgili siyasi konuları ne sıklıkla tartışırsınız?" sorusuna şu yanıtlar verilmiştir; ulusal düzeyde, vatandaşların \%50'si "ara sıra" tartıştıklarını belirtirken, \%28'i "hiçbir zaman", \%22'si ise "sıklıkla" 
tartıştıklarını ifade etmiştir. Avrupa düzeyindeki siyasi konular ise vatandaşların; \%48'i “ara sıra", \%40'ı "hiçbir zaman", \%11'i "sıklıkla" tartıştıklarını belirtmiştir. Burada dikkati çeken bir ayrıntı da şudur; Birlik düzeyindeki siyasi konuları en çok tartışan ülkeler; Danimarka, Avusturya ve Almanya olarak görülürken, bunun aksine en az tartışan ülkeler ise İspanya ve Portekiz vatandaşlarıdır.

Araştırmada vatandaşların büyük çoğunluğu aileleri ve bireysel yaşamları konusunda iyimser bir hava içinde oldukları halde, ülkelerinin geleceği konusunda belirgin bir karamsarlık gözlenmektedir. Ulusal düzeyde gidişatın kötüye doğru olduğunu düşünenlerin oranı \%43 iken, tam tersini düşünenlerin oranı $\% 34^{\prime}$ te kalmıştır. Diğer bir ifadeyle vatandaşların bugünkü durumuyla, yarının nasıl olacağına dair düşünceleri arasında önemli farklılıklar bulunmaktadır. Ulusal düzeyde işlerin kötüye gittiğine inanan vatandaşlar \%68 oranıyla Fransa, \%47 ile Portekiz ve \%45 ile İtalya ve İngiltere başı çekmektedir. Diğer taraftan, Baltık ülkeleri, Polonya ve İrlanda'nın diğer ülkeler arasında Avrupa Birliği'nde gidişatın iyi yöne doğru olduğuna dair bir tutum içinde bulundukları görülmektedir.

Ulusal ve Birlik düzeyinde vatandaşlara; "şimdiki durumda genel olarak olayların ne yöne doğru gittiğini söyleyebilirsiniz?" sorusuna alınan karş1lıklar şu biçimdedir; ulusal düzeyde vatandaşların \%34'ü gidişatın iyi yönde olduğunu düşünürken, $\% 43$ 'ü ise tam aksini düşündüklerini belirtmişlerdir. Birlik düzeyinde ise; vatandaşların \%39'u iyi yöne doğru gittiğini düşünürken, \%27'si kötü yöne doğru gittiğini belirtmişlerdir. Bu değerlendirme ülkeden ülkeye değişmektedir. 15 üyeli $\mathrm{AB}$ vatandaşlarının \%36's1 AB'de gidişatın olumlu yönde olduğunu düşünürken, 10 yeni üye ülkede bu oran \%53'e çıkmaktadır. AB'de gidişatın kötü yönde olduğunu düşünen karamsar ülkelerin başında \%48 oranıyla Fransa gelmektedir. Avusturya \%44 ile Fransa'y1 takip ederken; diğer karamsar düşünen ülke vatandaşları ise \%43 ile Finlandiya'dandır. Görüldüğü gibi, vatandaşların kendi ülkeleri için düşünceleri daha karamsar iken, Birlik düzeyinde bu karamsarlık daha olumlu bir havaya dönüşmektedir.

Vatandaşların gözünde $\mathrm{AB}$ ile özdeşleşen karakteristik özelliklere yönelik olarak araştırmadan çıkan sonuçlar ise şunlardır; görüş̧mecilerin büyük bir çoğunluğu AB'yi \%67'lik bir oranla "demokratik ve modern" olarak görmektedir. Yine, görüşmecilerin \%54'ü AB'yi “koruyucu”, \%49'u “teknokratik" ve son olarak \%43'ü “etkisiz" olarak tanımlamıştır. 


\section{Avrupa Birliği Vatandaşların Gözünde Avrupa Birliği'nin İmajına Yönelik Araştırma Sonuçları}

Avrupa'nın geleceğini şekillendirmek ve halkın düşüncesini iyi anlamak için $\mathrm{AB}$ 'nin halkın gözünde nasıl bir imaja sahip olduğunu ortaya koymak gerekmektedir. "Avrupa Birliği diye bir kelime duyduğunuzda aklınıza ilk ne gelir?" sorusuna karşılık olarak; \%22 oranıla işbirliği, beraberlik, eşitlik, ortaklık, kararlar, kurallar ve mevzuat, \%19 oranılla Avrupa, AB kurumları ve üyelik, \%15 ile tek para birimi Avro, \%11 ile tatil, turizm, iyi şartlarda çalışma, eğitim, sınır olmayan yer ve hareket özgürlüğü, \%9'luk bir oranla ise, ortak pazar, ticaret antlaşmaları, ekonomi, küreselleşme ve iş fırsatları cevapları verilmişstir.

Sonuçlarda göze çarpan ayrntılarda; soruyu cevaplayanların \%5'i AB kelimesini duyduğunda "ulusal kimliklerin kaybı""nın ilk akla gelen düşünce olduğunu belirtirken, \%3'ü "zaman kaybı" olarak düşündüğünü belirtmiştir. Detaylandınlmış sonuçlarda, üye ülkelerin $\mathrm{AB}$ ile ilgili bazı spesifik değerlendirmeleri aşağıda belirtildiği şekilde yer almaktadır (Special Eurobarometer, 2006): Belçikalı vatandaşların \%30'u, her şeyden önce AB'yi birlik, eşitlik, üye ülkeler arasında ortak kararlar ile eş anlamlı olarak düşünmektedir. Çek Cumhuriyeti vatandaşlarının \%13'ü, ülkelerinin $\mathrm{AB}$ üyesi olmasından dolayı üzüntülerini ifade etmişlerdir. Alman vatandaşlarının \%15'i, Avro'yu AB'nin esas sembolü olarak düşündüklerini ifade etmişlerdir. Yunan vatandaşlarının \%22'si, tek para ve \%17'si fiyat artışından dolayı üzüntü duyduklarını belirtmişlerdir. İspanya vatandaşları, her şeyden önce " $A B$ " sözcüğünü duyduklarında akıllarına üye ülkeler arasında işbirliği geldiğini ifade etmişlerdir. Fransız vatandaşlarının \%39'u, en başta AB'yi bir kurumlar serisi olarak görmektedir. \%7'si ise Avrupa seviyesinde karar verme sürecini çok hantal bulmaktadır. İtalyanların $\% 27$ 'si, AB ile ilgili olarak Avro'yu düşünmektedir. Kıbrıslı vatandaşlanın $\% 21$ 'i, AB sözcüğü ile fiyatların yükselmesini eş anlamlı olarak görmektedir. Letonyalı vatandaşların \%18'i, AB'ye üyeliği zaman kaybı olarak görürken, \%13'ü bunun aksine $A B$ 'nin ilerlemeyi temsil ettiğine inanmaktadır. Litvanyalıların \%15'i, bazı komşuları gibi $\mathrm{AB}$ 'ye şüphe ile yaklaşırken, \%21'i AB içinde değişkenliği istemektedir. Yüzde 22 oranında Malta vatandaşı, $\mathrm{AB}$ üyeliğinin getireceği ticaret, özellikle tek pazar sonucu oluşan firsatları ifade ederken, \%14'ü $\mathrm{AB}$ üyeliğinin kötü bir düşünce ve bir gerileme olduğunu düşünmektedir. Yüzde 38 Hollandalı için $\mathrm{AB}$, üye ülkeler arasında işbirliğini ifade etmektedir. \% 15 Hollanda vatandaşı için ise $\mathrm{AB}$, boş zaman ve para kaybı demektir. Avusturyalıların büyük çoğunluğu, nitelikli bir "Euro septik" olarak \%18 oranında vatandaş enflasyonundan 
söz etmektedir. \%16'sı, ülkelerinin AB'ye üyeliğinden dolayı hayal kırıklığına uğradığını ve \%13'ü ise, potansiyel olumsuzluğundan dolayı göçü belirtmektedir. Yüzde 23 Polonyalı için $A B$ sözcüğü, ilerleme veya daha iyi bir gelecek gibi pozitif bir anlama sahiptir. Portekiz vatandaşlarının 3 'te biri, AB'nin her şeyden önce kurumları çağrıştırdığını ifade etmiştir. Yüzde 35 Slovakyalı vatandaş, her şeyden önce $A B$ 'nin değişkenliği çağrıştırdığını ifade etmiştir. Yüzde 14 Finlandiyalı vatandaş, AB'ye üyeliğin zaman kaybı olduğunu düşünmektedir. Yüzde 21 İsveç vatandaş1, AB'ye üyeliğin bir zaman ve para kaybı olduğunu bildirmiştir. İngiliz vatandaşlarının AB'ye olumsuz bakışı, diğer ülkelerin ifade ettiklerinden fazla değildir.

\section{Avrupalıların Beklentilerine Yönelik Analizler}

Avrupalı vatandaşların Birlikten beklentileri siyasi ve sosyal olmak üzere iki alanı kapsamaktadır. Avrupa'nın geleceğinin en iyi biçimde sağlamanın yolları araştırıldığında ortaya çıkan sonuçlar arasında ilk sırada; "Avrupa'da yaşam standartlarının birbirine yakın olmasını sağlama" faktörünün olduğu görülmektedir. Ankete katılan her iki vatandaştan biri yaşam standartlarının yakınlaştırılmasının AB'nin geleceği için anahtar öğe olacağını düşünmektedir. 15 üyeli $\mathrm{AB}$ ülke vatandaşlarının \%47'si bu düşüncede iken, 10 yeni ülke vatandaşlarının \%74'ü bu fikre katılmaktadır. İkinci sıradaki faktör ise; "tüm üye ülkelerde Avro'nun kullanılmasının sağlanabilmesi” olarak düşünülmüştür. Bu konuda tüm üye vatandaşların $\% 26$ 'lık bir oy oranıyla bu fikre katıldıkları görülür. Üçüncü sırada \%25 ile "ortak bir anayasa oluşturmak" ifadesi gelmektedir. AB'nin geleceğine ilişkin verilen cevaplara karşıllk gelen 25 üye ülke vatandaşlarının oy oranları şu şekildedir: Benzer yaşam standardı: \%51; Avro'nun tüm AB ülkelerinde kullanılması: \%26; Ortak bir anayasa oluşturmak: \%25; Ortak bir dilin oluşturulması: \%22; Dış sınırların çok iyi biçimde korunması: \%11; Ortak bir ordu kurulması: \%9 (Special Eurobarometer, 2006).

$\mathrm{Bu}$ öğelerden 1. sırada yer alan; "benzer yaşam standardının oluşturulması", hemen hemen tüm üye ülkelerde AB'nin geleceğine ilişkin en önemli faktör olarak düşünülmektedir. Ülkeler bazında bakıldığında; İlanda, Lüksemburg ve Finlandiya vatandaşları Avrupa'nın geleceğini en iyi biçimde sağlayacak yolun başında "Avro'nun tanıtılması ve kullanımının yaygınlaştırılması"nın geldiğini düşünmektedir (sırasıyla bu görüşe katılım oranları; \%48, \%49 ve \%50'dir). Üçüncü sıradaki "ortak bir anayasa oluşturmak" fikri, 15 üyeli $\mathrm{AB}$ vatandaşlan tarafından \%27 oranında desteklenmiştir. Avrupa'nın geleceğinde en yararlı öğe olarak düşünülen 
“ortak bir dil geliştirmek" düşüncesi de en fazla \%34'lük bir oranla İrlanda, $\% 32$ ile İtalya, \%29 ile Portekiz ve \%28 ile İngiltere tarafından destek bulmuştur.

$A B$ vatandaşlarının siyasal beklentilerini içeren 13 ayrı politika alanında görüşmecilere; "Birliğin; Avrupa'nın geleceğinde daha fazla veya daha az oranda etkili bir politika yapmasını isteyip istemedikleri" sorulmuştur. Diğer bir ifadeyle AB'nin politikalara müdahale oranı belirlenmek istenmiştir. Aşağıda sıralanan politika alanlarında, "Birlik gelecekte Avrupa düzeyinde daha etkin kararlar mı almalı? Yoksa daha az etkin kararlar mı alması gerekir?" sorusuna verilen yanıtların oranı aşağıda görüldüğü gibidir. Politika alanları şu biçimde sıralanmıştır;

- Terörizmle mücadele

- Barış ve demokrasiyi dünyada geliştirmek ve desteklemek

- Organize suçlarla mücadele

- Araştırma ve buluşlar alanında işbirliği

- Çevreyi koruma

- Temel sağlık konularında önleyici tedbirler alma

- Enerji koşullarının devamını sağlama

- Yiyecek güvenliğirii sağlama

- Kadın ve erkeklere eşit muamele

- Ekonomik büyümeyi sağlama

- Tarımı koruma

- Sosyal haklari koruma

- İşsizlikle mücadele etme

$\mathrm{Bu}$ alanlarla ilgili olarak yapılan görüşmeden çıkan sonuçlara göre; görüşmecilerin \%80'i, Birliğin "terörizmle mücadele""de Avrupa düzeyinde daha az etkin olması gerektiğini düşünürken, \%12'si daha etkin olması gerektiğini düşünmektedirler. "Demokrasinin ve barışın dünyada geliştirilmesi” politikasını 2. sıraya koyan katılımcıların \%77'si, bu alanda Birliğin daha az etkili olması gerektiğini savunurken, \%12'si, daha etkin kararlar alması gerektiğini düşünmektedir. Bu alanlar içinde Birliğin en fazla etkin olması gerektiği düşünülen alanlar; \%28 oranıyla "ekonomik büyüme", \%30 ile "tarımı koruma", \%32 ile "sosyal hakları koruma" ve en çok Birliğin etkin olması istenilen politika alanı \%37 ile "işsizlikle mücadele" olmuştur. 


\section{Avrupa Birliği'nin Performansının Değerlendirilmesi}

$\mathrm{Bu}$ araştırmada; çeşitli alanlarda görüşmecilere sorular yöneltilerek AB'nin ne kadar başarılı olduğu hakkında görüşleri sorulmuş ve daha az başarılı olduğu alanlar ortaya çıkarılarak, AB'nin performansı değerlendirilmiştir. Burada ölçeğe 1-10 arası değerler verilmiştir. Değerlendirmeyi yapan kişiler, AB'nin en başarılı olduğu alandan en az başarılı olduğu alana doğru verdikleri 1-10 arası değerlerin ortalamasını alarak aşağıdaki değerler elde etmişlerdir (Special Eurobarometer, 2006);

- Araştırma ve buluşlar alanında işbirliği: (5.8)

- İnsan haklarını koruma: (5.7)

- Kadın ve erkeklere eşit muamele: (5.6)

- Barış ve demokrasiyi dünyada geliştirmek ve desteklemek: (5.6)

- Yiyecek güvenliğini sağlamak: (5.5)

- Terörizmle mücadele etmek: (5.4)

- Temel sağlık konularında önleyici tedbirler almak: (5.4)

- Enerji koşullarının devamını sağlamak: (5.3)

- Çevreyi korumak: (5.3)

- Organize suçlarla mücadele etmek: (5.2)

- Tarımı Korumak: (5.1)

- Dünyadaki yoksul halklara yardım etmek: (5.1)

- Ekonomik büyümeyi sağlamak: (4.9)

- Sosyal haklar korumak: (4.7)

- İşsizlikle mücadele etmek: (3.8)

Politika alanları 3 gruba ayrlarak değerlendirildiğinde şu sonuçlar ortaya çıkmaktadır; 1. grupta AB'nin performansının daha olumlu olarak görüldü̆ğu alanlar; "araştırma ve buluşlar alanında işbirliği", "kadın ve erkeğe eşit muamele" ve "demokrasi ve barışın dünyada geliştirilip desteklenmesi" dir. Diğer iki gruba oranla iyi durumda olsa bile katılımcılar bu alanlarda AB'nin çaba sarf etmeye devam etmesini ve şimdiki durumu korumasinı istemektedirler. 2. grupta; güvenlik ve çevresel konular ardından coğrafi sınırlar ve organize suçlar politikalarında, AB'nin performansı ortalama olarak değerlendirilmiş; ancak özellikli noktalarda, AB'nin çok daha fazla çaba göstermesi gerektiği, araştırmada yer alan vatandaşların büyük çoğunluğu tarafından kabul görmüştür. Son grupta ise; issizlikle mücadele, ekonomik büyüme, sosyal haklar ve tarım yer almaktadır. Bu konularda vatandaşların büyük çoğunluğunda $A B$ 'nin şimdiki performansı hayal kırıklığı yaratmıştır denilebilir. Diğer bir ifadeyle, AB bu konularda 
güvenilirliğini ve meşruluğunu artırmak için çok daha fazla ikna edici yönde çaba göstermelidir.

\section{Avrupa'da Vatandaşlık}

$\mathrm{Bu}$ başlık altındaki araştırmada; katılımcılara Avrupa vatandaşlığına ilişkin sorular yöneltilerek vatandaşların Avrupa vatandaşı olma hissini neyin sağladığı ortaya konulmak istenmiştir (Special Eurobarometer, 2006). "Size Avrupa vatandaşı olma hissini vermeyi ne sağlar?" sorusuna verilen yanıtlar şu biçimdedir; bu sorunun sorulduğu kişilerin 1/3'ü \%32'lik bir oranla "Avrupa'da sosyal yardım sisteminin olması" karşılığını vermiştir. İkinci olarak, \%27'lik bir oranla "bir Avrupa Anayasası" isteğinin ardından, \%21 ile "kişilerin ikamet ettiği ülkede yapılan tüm seçimlerde oy kullanma hakkı" gelmiştir. Dördüncü sırayı alan görüş ise "doğrudan AB başkanını seçmek" ile \%16'lık oranla yerini almıştır. "Bunlardan hiçbiri" diyen görüşlerin oranı $\% 12$ olurken, "ulusal vergi yerine $\mathrm{AB}$ vergisinin oluşturulması" fikri \%11 olarak belirtilmiştir. Görüşmeye katılanların \%8'i ise "Avrupa vatandaşı olmak istemiyorum" yönünde görüş bildirmiştir.

Genel sonuçlara bakıldığında, 10 yeni ülke vatandaşları 1. sıradaki "sosyal yardım sistemi" düşüncesine $\% 52$ oranında katılırken, 15 üyeli AB vatandaşlarının katılım oranı ise \%29'dur. Sıralanan düşüncelere katılım oranları üye ülkeler arasında değişiklik göstermektedir. "ortak bir Anayasa oluşturulması" fikrine en fazla katılan ülkeler; \%44 ile Belçika, \%37 ile Hollanda, \%35 ile Estonya ve \%34 oy oranıyla Almanya'dır. "Kişinin yaşadığı ülkede tüm seçimlere katılma" düşüncesine en fazla evet diyen ülkeler ise; \%50 ile Danimarka, \%45 ile İrlanda, \%45 ile Lüksemburg, \%40 ile Malta ve \%38 ile İsveç'tir.

İlginç bir nokta olarak şu gözlenmiştir; “Avrupa vatandaşı olmak istemiyorum" diyen \%12'lik oranın \%2'si İngiliz vatandaşlanına aittir. Sonuçlardan çıkan başka bir ayrıntı da şudur: "Ortak bir anayasa oluşturmak" fikrine hayır diyenlerin oranı olan \%12'lik kesim aynı zamanda $\mathrm{AB}^{\prime}$ 'ye üye olmanın kötü bir şey olduğuna inanmaktadır. Konuyla ilgili olarak sorulan "Avrupa düzeyinde vatandaşın sesini duyurmasinın en iyi yolu nedir?" sorusuna verilen 1. sıradaki yanıt \%56 ile "seçimlerde oy kullanma"'dır. İkinci olarak, \%15 oy oranıyla "Parlamentoya dilekçe vermek" gelmektedir. Üçüncü olarak, \%13 oranıyla "siyasi bir partiye üye olmak" gelirken, \% 10'luk bir oranla "gösteri yürüyüşü yapmak", \%9 ile "bir sendikaya üye olmak" gelmektedir. Aynı oy oranıla "tüketici derneğine üye olmak" yer alırken, \%8'lik bir oranla da "greve gitme" olduğu yönünde 
görüşler ortaya çıkmıştır. Ülkelere bakıldığında; bu cevaplara yönelik olarak önemli farklılıkların olmadığı görülmektedir.

Bir başka konu ise "Avrupa düzeyinde müzakere ve istişarelere katılmaya istekli olmak”tır. Bu başlık ile ilgili olarak yapılan araştırmalarda amacın vatandaşların siyasi hareketliliğinin derecesini ölçmeye çalışmak olduğu belirtilmiştir. Bir başka amaç ise, "yurttaş inisiyatifi" olarak görülen 'Avrupa Anayasası'na yönelik değerlendirmeleri ölçmektir. Bu konuda yapılan gözlemlerden biri; $\mathrm{AB}$ vatandaşlarının tüm Avrupa düzeyinde aynı gün yapılan halk oylamalarını seslerini duyurmak için kullandıklan diğer araçlara (kendi ülkelerinde yapılan seçim, imza toplama, meclise dilekçe verme vb.) göre daha ilgi çekici bulduklarıdır. Avrupa düzeyinde müzakerelere ilişkin katılıma en fazla istekli olan ülke, \%73'lik bir oranla Danimarka'dır. Onu \%55 ile İsveç ve \%52 ile Lüksemburg izlemiştir. Hollanda ve Fransa'nın oy oranı ise sırasıyla $\% 47$ ve $\% 41$ 'dir. 25 üye ülke içinde katılıma en az istekli ülke \%10 ile Portekiz gelmektedir. Bu konudaki araştırmadan bir sonuç çıkarılacak olursa; genel olarak AB vatandaşlarının karar alma sürecine katılmaya istekli oldukları söylenebilir.

\section{Avrupa Birliği Vatandaşlarının Küreselleşmeye Yönelik Tutumları}

Avrupa'nın geleceğinde, kuşkusuz ekonomik büyümeyle beraber ilerleyen küreselleşme olgusu ve $A B$ vatandaşlarının da bu olguya yönelik tutumları önemli yer tutmaktadır. Bu konuyla ilgili olarak yapılan araştırmada, görüşmeye katılan vatandaşlara 3 ifade sunularak, kendilerine uygun görüşü cevaplandırılmaları istenmiştir. Bu ifadeler şunlardır (Special Eurobarometre, 2006):

- Küreselleşme yeni pazarlar oluşturmak için şirketlere iyi firsatlar sunar

- Küreselleşme çalışanlar ve şirketler için bir tehdit oluşturur

- Fikrim yok

Görüşmeye katılan vatandaşların \%47'si; küreselleşmenin bir tehdit unsuru olabileceğini düşünürken, bunun aksini düşünenlerin oranı \%37'de kalmıştır. 2003 yılında 15 üyeli $\mathrm{AB}$ vatandaşlanına aynı soru sorulduğunda "küreselleşmeyi", bir fırsat olarak değerlendirenlerin sayısı şimdikinden yaklaşık 20 puan fazla olarak \%56'larda kabul görmüştür. Ülkeler bazında duruma bakıldığında; 25 üye ülke içinde sadece 11'inde "küreselleşme" çalışanlar ve şirketler için bir fırsat olarak görülmüştür. Danimarka ve İsveç vatandaşları "küreselleşme" ye karşı daha olumlu bir yaklaşım sergileyerek 
$\% 77$ ve $\% 54$ oranıyla destek vermişlerdir. Diğer taraftan "küreselleşme" den en çok endişe eden ülkeler ise; \%72 ile Fransa ve Yunanistan, \%64'lük oy oranıyla Belçika'dır.

Küreselleşmeye yönelik endişelerin ifade bulduğu bir alan olarak, ortak bir Avrupa Birliği Anayasal Sözleşmesi'nin oluşturulması çabasına gösterilen tepkiden de sözedilebilir. Avrupa için Anayasa Sözleşmesi'nin 2005 yilında hem Fransa hem de Hollanda gibi iki kurucu ülkede yapılan referandumlarda reddedilmesi, Birlik içinde gelişen ekonomik ve sosyal kaygıların, küreselleşmenin getirdiği tehdit algısının giderilmesi için bazı girişimlerin gereğine işaret etmektedir. Avrupa sorunlanını tespit etmede ve bunlara çözüm bulmada $A B$ kurumlan ve çevresindeki elitlerin görüşleri ve halkın görüşleri kesişmekte mi yoksa çatışmakta mıdır? Adı geçen iki ülkede de iktidardaki güçler ve medya, Anayasal Sözleşmeyi büyük çapta desteklemekte oldukları halde, halkın çoğunluğu referandumu, Avrupa projesi simgesinin bütününe karşı duruşlarını belirtecek bir araç olarak kullanmıştır. (Selin Girit, 2006) Gerçi Avrupa Anayasa Sözleşmesi üzerinde bugün halkın daha pozitif görüşler ifade ettiği görülmektedir (Standard Eurobarometer, 2006). Henüz ülkelerinde Sözleșme'nin kabul edilmemiş olduğu halkların yarısından çoğu (\%53), İlkbahar 2006 dan bu yana 6 puan bir artışla ortak Anayasa'yı desteklemektedir. Bu konuda fikrim yok diyenlerin oranı da \% 24 düzeyinden \% 19'a düşmüştür. Özellikle Fransa ve Hollanda'da ilkbahar 2006 dan itibaren, 5 ve 6 puan artışlarla birlikte, Anayasa'yı destekleyenlerin oranı \% 56 ve \% 59'a yükselmiștir.

Elli yıldır geleneksel tepeden inme bir çizgide politikalar yürüten Avrupa Birliği, önemli adımların önünü açan kararları almadan önce Birlik düzeyinde halk tartışmalarına ve halkın görüşlerinin ifade ve yorumuna olanak tanımayı ve kararlar alındıktan sonra halka danışma sürecini tersine çevirmeyi artık öğrenmektedir. Halkın, Avrupa düzeyindeki konularla ilgilenmediği, yalnızca ulusal düzeyde siyasete katılmayı yeğlediği gibi ifadelerin yanlışlığı, halk görüşleri çalışmaları yoğunlaştıkça ve genişletildikçe daha iyi anlaşılmaktadır. AB halkının Avrupa Parlamentosu'nu Birlik içinde en güvenilir kurum olarak görmesi (\%52) gerçeği de yöneticiler için bir ipucu teşkil etmelidir. Avrupa Birliği Komisyonu'na duyulan halk güveni ise \% 48'dir. (Standard Eurobarometer, 2006) 


\section{Avrupa Birliği'nin Genişlemesi}

$\mathrm{AB}$ vatandaşlarının Birliğin genişlemeye yönelik algılamalarına bakıldığında genel olarak şunlar söylenebilir (Special Eurobarometer, 2006); Öncelikle iki Avrupalıdan biri AB'nin genişlemesini olumlu olarak algılamaktadır (\%55). Yeni katılan üye ülke vatandaşları bu konuda daha pozitif bir tutum sergileyerek \%69'luk orana ulaşmıştır. 15 üyeli AB üye ülke vatandaşları ise her iki gruptan daha az bir oran olan \%53 ile yanıt vermişlerdir. Araştırmadan çıkan sonuca göre 3 ülkede, diğer ülkelere nazaran çoğunluk genişlemeye karşı olumsuz bir karşılık vermişlerdir. Bu ülkeler; Avusturya (\%52), Fransa (\%52) ve Finlandiya (\%50)'dır.

"Avrupa Birliği'nin genişlemesi olumlu bir adım mıdır?" sorusuna karşıllı en büyük destek \%76'lık bir oranla Slovenya, \%73 ile Polonya, \%71 ile Kıbrıs, \%66 ile İsveç'ten gelirken, en az destek Birliğin 15 üye ülke vatandaşlarından gelmiştir. Avusturya \%40, Fransa \%44, Finlandiya \%45, Lüksemburg \%48, İngiltere \%49, Portekiz \%52, Almanya \%52 ve İspanya $\% 55^{\prime}$ tir. Genişleme konusundaki bu olumlu havaya rağmen vatandaşlar, Birliğin bundan sonraki genişleme girişiminden çok, "işsizlikle mücadele etme" ile ilgilenmesi gerektiğini belirtmiştir. $\mathrm{Bu}$ görüşü kuvvetle destekleyen ülkelerin başında \%82 ile Kıbrıs, \%80 ile Almanya, \%75 ile Avusturya ve Fransa gelmektedir. "AB'nin bundan sonraki genişlemesiyle ilgili görüşme ve tartışmaları duyduğunuz zaman ilk ne hissedersiniz?" sorusuna verilen karşılık; \%30 ile "umut", \%12 ile "umursamazlık", \%15 ile "korku", \%12 ile "kızgınlık", \%9 ile "hüsran", \%8 "memnuniyet" ve \%4 ile "heyecan" olmuştur. Ülkeler bazında sonuçlara bakıldığında; Avusturya, Fransa ve Finlandiya vatandaşlarının hislerinin olumsuz olduğu ortaya çıkmıştır. Lüksemburg ve Alman vatandaşlarının yaklaşık çeyreği (\%23\%29) "korku” duygusuna kapıldıklarını ortaya koymuşlardır.

\section{Sonuç}

Avrupa Birliği, ekonomik bir Birlikten öteye bir değerler Topluluğu oluşturmakta, toplumsal bir yaşam modeli ve siyasi kültür birikimi sunmaktadır. Avrupa Birliği'nin dayandığı özgürlük, demokrasi, hukuk devleti, insan hak ve özgürlüklerine saygı ilkeleri, $A B$ yurttaşları ile $A B$ arasında, aynı ulusal devlet düzeyinde devlet ile vatandaşı arasında olduğu gibi bir aidiyet bağı oluşturmaya çalışmaktadır. AB, ortak kimlik ve Avrupa kamuoyu aracılığıyla egemenliğinin meşruiyet dayanağını oluşturma çabaları arasında, Eurobarometre çalışmalarına yer vermektedir. 
Kamu iletişim araçlarından biri olarak görülmesi ve önemsenmesi gereken Eurobarometre çalışmaları, içerik olarak kişileri yalnızca ulusal düzeyde görüş beyan etmekle yetinmeyerek, Avrupa düzeyine yönelik konularda da düşünmeye sevk etmektedir. Böylece küreselleşme, savaş ve terör tehdidi, sağlık, çevre gibi tüm insanları ortak olarak ilgilendiren konularda bir Avrupa kamusal alanı yaratılması teşvik edilebilir. Birliğin geleceğinin şekillenmesinde, modern demokratik yönetimlerin en önemli aktörü olan halkların, gelişen süreçte nasıl bir tavır içinde olduklan büyük önem arz etmektedir. Eurobarometre araştırmalarındaki halk görüşleri analizleri, demokrasi için öngörülen diyalog ve tartışma etrafında Avrupa'nın geleceği üzerine halkın nabzını tutmakta başarılı olmaktadır.

Göstergelere bağlı bakış açısına göre; Avrupalılar kendi kişisel ve mesleki durumlan ile ilgili memnuniyetlerini ifade etseler de belirgin bir karamsar hava gözlenmektedir. Bu karamsarlık, özellikle vatandaşların küreselleşme, bir sonraki genişleme ve ulusal düzeyde yanlış yönlendirilme düşüncesi konularındaki korkularından kaynaklanmaktadır. Birlik düzeyinde yönetim ile ilgili konularda iyimserlerin oran fazla görülmektedir. Başka bir ifadeyle; Avrupa düzeyinde henüz her şeyin denenmediği ve çoğunluğun Birlik düzeyinde karar alınmasinı desteklediği görüşü bulunmaktadır. Vatandaşlar, Birlik içinde tüm üyeleri etkileyen sorunlar için işbirliği, dayanışma, eşitlik, ortak karar ve kurallar konusunda birlikte ortak çözümler bulma düşüncesinin iyi olacağı kanaatini taşımaktadırlar.

Yapılan analizlerde; AB'nin olumlu bir "imaja" sahip olduğu ortaya çıkmıştır. Birlik, "demokratik", "modern" ve "koruyucu" olarak algılanmaktadır. Ancak tüm bunlarla beraber, AB'nin en sadık destekleyicileri bile, Birliğin "teknokratik" ve gözle görülür bir düzeyde "etkisiz" karakterinden dolayı onu eleştirmekten kaçınmamıştır. Ankete katılan her iki kişiden biri, AB'ye üyeliğin olumlu bir durum olduğunu düşünmektedir. Buna rağmen, Birlik düzeyinde siyasi ve kültürel entegrasyon eksikliği konularında vatandaşlar memnuniyetsizliklerini dile getirmişlerdir.

Birliğin genel olarak başarı durumuna bakıldığında; eğer $\mathrm{AB}$ 'yi kuran "kurucu babaların" belirlemiş oldukları hedefler göz önüne alınırsa, "barış ve iç pazar" açısından AB'nin başarılı olduğu söylenebilir. Eleştiriler Avrupalı vatandaşlar için en önemli konular olarak görülen; işsizlik, sosyal hakların korunması ve ekonomik büyüme konularında yoğunlaşmaktadır. 
$\mathrm{Bu}$ belirli alanlarda vatandaşlar; $A B$ 'nin performansını zayıf olarak değerlendirmişlerdir.

Vatandaşlar, Avrupa'nın geleceğini belirleyecek olan en önemli unsurun; benzer yaşam standartlarının olduğunu düşünmektedir. İkinci olarak, Avro'nun tüm ülkelere girmesini ve üçüncü olarak da ortak bir anayasa oluşturmayı en önemli unsurlar olarak görmektedirler. Yine vatandaşların kendilerini Avrupalı hissetmelerini güçlendiren unsurların başında, sosyal güvenlik sistemi, bir Avrupa Anayasası ve oturdukları ülkede yapılan tüm seçimlerde oy kullanma hakkı olduğu ortaya çıkmaktadır.

Avrupa vatandaşları, seslerinin karar vericiler tarafından duyulmasını sağlamak için hala temsili demokrasinin geleneksel biçimlerini desteklemektedirler. Gerçekten de modern katılım biçimlerini reddetmeden, bunları diğer katılma biçimlerine tercih etmektedirler. Bununla beraber, daha ihmal edilebilir bir düzeyde, AB'yi ilgilendiren konularda tüm ülkelerde aynı gün yapılan gerçek bir Avrupa referandumu fikrine de istekli yaklaşmaktadırlar.

Eurobarometre araştırmalarından çıkan sonuçlar bir cümle ile ifade edilecek olursa şu söylenebilir; Avrupalılar, Avrupa ile ilgili olarak korku ve beklentilerini eş zamanlı olarak ortaya koymaktadırlar. Dayanışma içinde güçlü bir Avrupa gerçekleştirmek; "ekonomik, sosyal ve birlikte yaşam" alanlarında güvenirliğin artırılmasının garanti edilmesi halinde mümkün gözükmektedir. Eurobarometre araştırmasındaki halk görüşleri analizleri; demokrasi için öngörülen diyalog ve tartışma etrafında Avrupa'nın geleceği üzerine halkın nabzını tutmayı amaçlamaktadır. Avrupa'nın geleceğini hazırlamak, tartışmaları yeniden başlatmak ve Avrupa vatandaşlarının beklentilerinin üzerinde tutmak, bu süreçte daha önemli hale gelmiştir.

Eurobarometre kapsamında yapılan araştırmalarda, ortaya çıkan genel sonuçlara göre, Avrupa vatandaşlarının öncelikle $A B$ hakkında olumlu bir imaja sahip oldukları görülmektedir. Vatandaşlar AB'yi demokratik, modern ve koruyucu olarak algılamaktadır. Yine vatandaşların yarısından fazlası $A B$ 'ye üye olmaktan memnun görünmektedir. İlginç olan, vatandaşların kendi ülkeleri için düşünceleri daha karamsar iken, Birlik düzeyinde bu karamsarlık daha olumlu bir havaya dönüş̧mektedir. Dikkati çeken önemli bir nokta ise yeni üye olan 10 ülkenin 15 üye ülkeden daha iyimser bir bakış açısına sahip olmalarıdır. Yine ortaya çıkan bu olumlu havaya rağmen vatandaşlar, $A B$ 'yi bir çok açıdan eleştirmekten geri kalmamışlardır. Özelikle, Birlik barış, ekonomik işbirliği ve bütünleşme 
konularında başarılı bulunurken, siyasi ve kültürel bütünleşme konusundaki eksikleri, işsizlik, sosyal hakların korunması ve ekonomik büyüme konularında eleştiriler yoğunlaşmaktadır. Bu alanlarda üye ülke vatandaşları $A B$ 'nin performansını zayıf olarak değerlendirmişlerdir.

Halk görüşleri analizlerinde; Avrupalılar kendi kişisel ve mesleki durumları ile ilgili memnuniyetlerini ifade etseler de belirgin bir karamsar hava gözlenmektedir. Bu karamsarlık, özellikle vatandaşların küreselleşme, bir sonraki genişleme ve ulusal düzeyde yanlış yönlendirilme düşüncesi konularındaki korkularından kaynaklanmaktadır. Birlik düzeyinde yönetim ile ilgili konularda, iyimserlerin oranı fazla görülmektedir. Başka bir ifadeyle; Avrupa düzeyinde henüz her şeyin denenmediği ve çoğunluğun Birlik düzeyinde karar alınmasını desteklediği görüşü bulunmaktadır. Vatandaşlar, Birlik içinde tüm üyeleri etkileyen sorunlar için işbirliği, dayanışma, eşitlik, ortak karar ve kurallar konusunda Birlikte ortak çözümler bulma düşüncesinin iyi olacağı kanaatini taşımaktadırlar. Avrupa'nın geleceğini belirleyecek en önemli unsur olarak, yaşam standardının birbirine yakın olması ve sosyal güvenlik sistemi düşüncesi, vatandaşların ekonomik kaygılarla ne kadar iç içe olduğunu göstermektedir. Araştırma sonuçlarında; gençlerin işsizlikle mücadeleyi Birliğin çözmesi gereken en önemli öncelik olarak görmeleri ve Avrupa'nın geleceğini belirlemede en önemli unsur olarak bir Avrupa Anayasası olmasını talep etmeleri, 2004 yılında üye ülkelerin imzalarına açılan Anayasal Antlaşma'nın Fransa ve Hollanda'da reddedilmesinin gerçekte, Anayasaya karşı bir hareket olarak algılanmaması gerektiği, bunun genişleme ve dolayısıyla işsizlikle ilgili olarak ekonomik kaygılardan kaynaklandığı sonucunu doğurmaktadır.

\section{Kaynakça:}

Calhoun, C. (2004). The Democratic Integration of Europe. Social Science Research Council. Erişim: 13.09.2006, http://www.eurozine.com/ articles/2004-06-21-calhoun-en.html.

Canbolat, İ. S. (1998). Uluslararası Sistem, Avrupa Birliği: Bir Dönüşüm Analizi. İstanbul: Alfa Basım Yayım.

Duparch, C. (1992). Avrupa Topluluğu ve Insan Haklart. Ankara: Avrupa Komisyonu Türkiye Temsilciliği Yayını.

Eder, K., Giesen, B. (2001). European Citizenship: Between National Legacies and Postnational Project\$oxford: Oxford University Press. 
Girit, S. (2006). 'Reasons Behind the 'No' Vote to the European Constitution: The Cases of France and the Netherlands'. Unpublished Master's Thesis in European Studies. İstanbul: Marmara University, European Community Institute.

Gözler, K. (2001). Anayasa Hukukuna Giriș: Genel Esaslar ve Türk Anayasa Hukuku. Bursa: Ekin Kitabevi Yayınları.

Habermas, J. (2000). Kamusallı̆̆ı Yapısal Dönüşümü, Çeviren: Tanıl Bora, Mithat Sancar. İstanbul: İletişim Yayınları.

Lord, C. (1998). Democracy in the European Union. Sheffield: Sheffield Academy Press.

Schmidt, M. G. (2002).. Demokrasi Kuramlarına Giriş, Çeviren: M. Emin Köktaş, 2. Baskı. Ankara: Vadi Yayınları.

Schmitter, C. P. (2000). How to Democratize the European Union and Why Bother? London: Rowman and Littlefield Publishers, Inc.

Selçuk, S. (1999). Demokrasiye Doğru. Ankara: Yeni Türkiye Yayımları.

Streek, W. (2001). Citizenship under Regime Competititon: The Case of European Work Councils. Erişim: 15.09.2006, http://eurozine.com/ articles/13.09.2006.eurozine-en.html.

Şaylan, G. (1980). Çağdaş Siyasal Sistemler. Ankara: Türkiye ve Orta Doğu Amme İdaresi Enstitüsü Yayınları, No. 192.

The Eurobarometer Web Site (2006). Erişim: 20.09.2006, http://ec.europa.eu/public_opinion/index_en.htm.

The Special Eurobarometer (2006). Erişim: 20.09.2006, http://ec.europa.eu/ public_opinion/archives/eb_special_en.htm.

The Standard Eurobarometer (2006). Erişim: 20.09.2006, http://ec.europa.eu/public_opinion/archives/eb/eb66/eb66_highlights_en. pdf.

Tanilli, S. (1990). Devlet ve Demokrasi: Anayasa Hukukuna Giriş, 6. Bask1. İstanbul: Say Yayınları.

Tekinalp, Ü. \& Tekinalp, G. (2000). Avrupa Birliği Hukuku. İstanbul: Beta Yayınları.

Weiler, J.H. (1999). The State 'über alles' - Demos, Telos and the German Maastricht Decision. NYU School of Law, Jean Monnet Center. Erişim: 28.09.2006, http://www.jeanmonnetprogram.org/papers/95/9506ind.html 